\title{
Composition and transport of settling particles in Lake Zuriclı: relative importance of vertical and lateral pathways
}

\author{
Erich Wieland ${ }^{1}$, Peter Lienemann ${ }^{2}$, Silvia Bollhalder ${ }^{3}$, Alfred Lück ${ }^{3}$ \\ and Peter H. Santschi ${ }^{4}$ \\ 1 Paul Scherrer Institute, CH-5232 Villigen PSI, Switzerland \\ 2 Swiss Federal Laboratories for Materials Testing and Research (EMPA), CH-8600 Dübendorf, \\ Switzerland \\ 3 Swiss Federal Institute for Water Resources and Water Pollution Control (EAWAG), \\ CH-8600 Dübendorf, Switzerland \\ ${ }^{4}$ Dept. of Oceanography, Texas A \& M University, Galveston, TX 77551, USA
}

Key words: Settling particle composition, sediment focusing, Lake Zurich.

\begin{abstract}
Time- and space-dependent variations in the composition of settling particles were investigated along a longitudinal transect in Lower Lake Zurich. The study was carried out during summer stratification using a two-dimensional array of sediment traps deployed in the hypolimnion. Samples of the sedimentary material were analysed for total $\mathrm{C}$ and total $\mathrm{N}, \mathrm{P}, \mathrm{Ca}, \mathrm{Si}, \mathrm{Al}, \mathrm{Fe}, \mathrm{Mn}$, $\mathrm{Mg}, \mathrm{Na}, \mathrm{K}$, and the trace elements $\mathrm{Zr}, \mathrm{Sr}, \mathrm{Rb}, \mathrm{Ti}, \mathrm{Ba}, \mathrm{S}, \mathrm{Pb}$ and $\mathrm{Zn}$. The elements can be classified according to their preferences in associating with a specific carrier phase. The fluxes and composition of trapped particles were found to vary seasonally with fluctuations in the main components (organic matter, calcium carbonate, biogenic silica, manganese and iron oxides, silicates) and spatially due to the following in-lake processes: 1) increasing vertical particle transport of biomass and mineralic material in the shoreward direction, 2) lateral sediment transport, which caused sediment accumulation rates to increase with depth, leading to sediment focusing, 3) episodic and patchy events of $\mathrm{CaCO}_{3}$ precipitation in the epilimnion followed by sedimentation and lateral dispersion, and 4) formation of a patchy nepheloid layer in the slightly denser bottom waters containing more fine-grained particles in suspension. Sediment focusing by lateral pathways caused by particle transport between the southern and the northern basin of Lower Lake Zurich gave rise to post-depositional in-lake redistribution of particle-bound contaminants.
\end{abstract}

\section{Introduction}

Sedimentation of pedogenic and aquagenic particulate matter is a fundamental process governing the transport and distribution of nutrients and contaminants scavenged by settling particles in aquatic systems (e.g., Santschi, 1984; Sigg, 1985; Eadie and Robbins, 1987; Murray, 1987; Sigg et al., 1987). This can be documented from measurements based on sediment traps deployed in vertical series on a single 
mooring array. While common for oceanographic studies, only few studies have addressed causes for temporal and spatial variations of particle fluxes in lakes (Chambers and Eadie, 1981; Bloesch and Uehlinger, 1986). The basic process of resuspension and sediment focusing in lakes have previously been described (e.g., Hakanson and Jansson, 1983; Hilton, 1985; Hilton et al., 1986; Bloesch; 1995). Boundary inputs by rivers at varying depths and lateral inputs from bottom sediment resuspension result in sediment focusing indicated by horizontal differences in particle mass fluxes. For example, sediment focusing was found to be important for the long-term accumulation of contaminants in the Great Lakes (Eadie and Robbins, 1987), and lateral transport significantly modifies particle transport in the ocean along the continental shelf (e.g., Biscaye et al., 1988). Eadie and Robbins (1987) documented sediment focusing in the Great Lakes as the consequence of episodic cycles of resuspension and redeposition of sedimentary matter. Winddriven waves in the near-shore and shallow waters and internal waves and currents in deeper waters cause resuspension and dispersion further away from their first place of deposition in the sediments. Biscaye et al. (1988) concluded that the lateral and net downslope transport of "virgin" particulate matter is the main mechanism accounting for the increase in the ${ }^{210} \mathrm{~Pb}$ flux with depth along the continental slope. Due to the closer proximity of horizontal and vertical boundaries in lakes, boundary effects may be of greater significance in freshwater environments.

Previous studies provided evidence for sediment focusing in Lake Zurich (Schuler et al., 1991; Wieland et al., 1991). Episodic events of high radionuclide fluxes not related to wind energy over the lake surface were measured in a near-bottom sediment trap during summer stratification. It was hypothesised that fine-grained particles were transported from shallow to deeper-lying sediments in the centre of the lake thus enhancing particle and radionuclide fluxes with depth. A lateral contribution to particle flux due to downslope transport of resuspended sedimentary material or an unconsolidated layer of flocculent particles (i.e., "virgin" particles) along the sloping sediments was suggested to be the main cause of sediment focusing. During stratification, density currents or; as hypothesised by Garett (1990), tertiary water motion near the bottom on the slopes of lakes, which is induced by secondary currents, can be the driving forces for the downslope particle transfer.

The present study was designed to further investigate the role of lateral and downslope particle movements. The aim of the study was to better understand depositional pathways of particle-reactive organic contaminants, heavy metals and radionuclides. The specific features of the lower basin of Lake Zurich make this lake ideal for investigating downslope particle transfer (see Fig.1). This paper reports on a sedimentological-geochemical strategy to characterise settling material and to investigate the vertical and lateral flux of particulate matter in Lake Zurich.

\section{Study site}

Lake Zurich is a U-shaped pre-alpine hard-water lake along the northern rim of the Alps. The shape of the lake originates from a weakened zone along the rightlateral strike slip fault overprinted by glaciers (Hsü and Kelts, 1970). Lake Zurich is divided by a dam-forming, late glacial moraine into the Upper Lake (Zürich- 


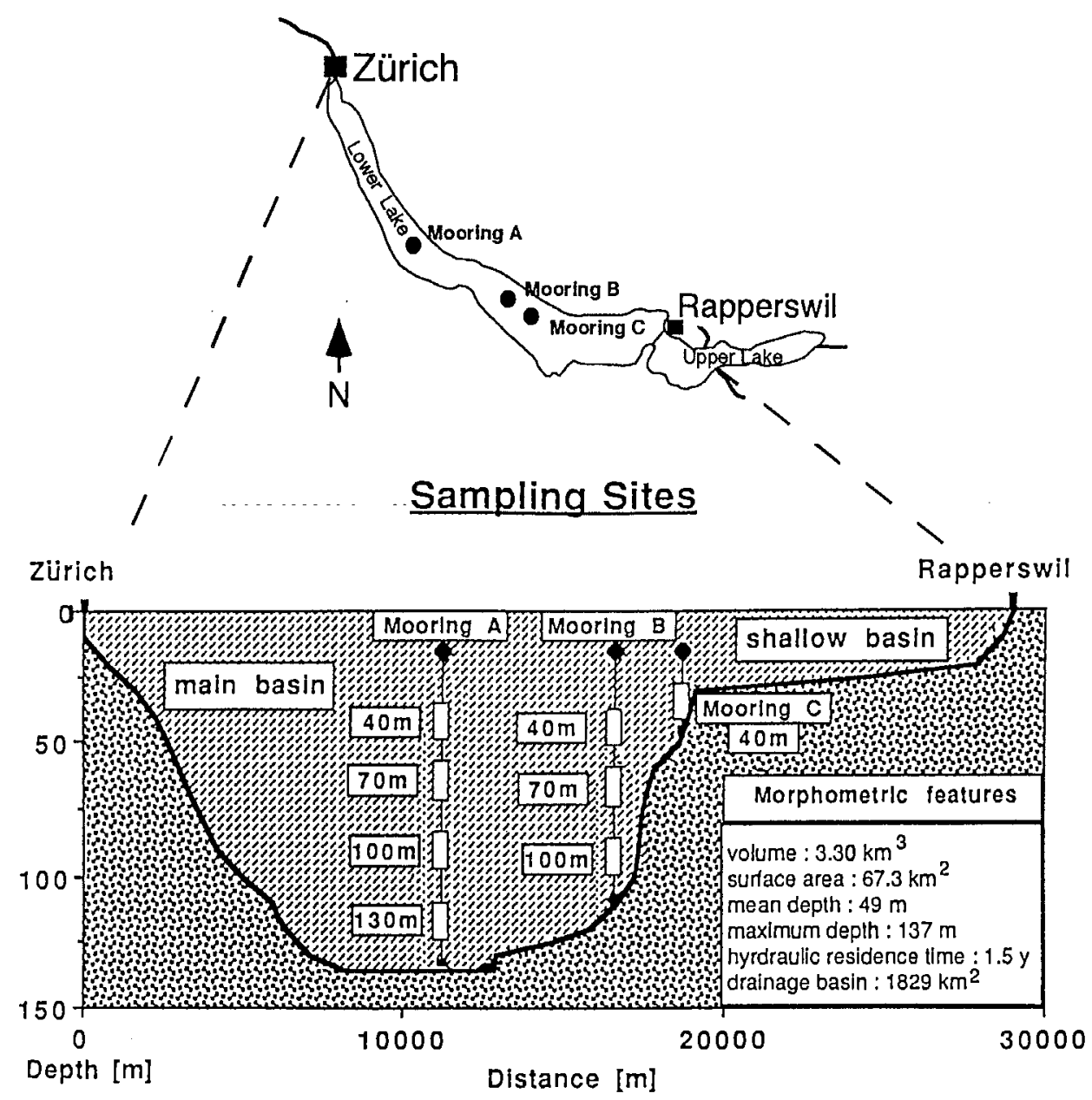

Figure 1. Sampling sites in Lake Zurich. The longitudinal section shows the locations of the sediment traps. Insert: physical parameters for Lake Zurich

obersee) and Lower Lake (Zürichsee) which are connected by a narrow channel with a sill depth of about $2 \mathrm{~m}$ (Fig. 1). Lower Lake Zurich also has two sub-basins separated by a subaqueous rock barrier. The shallow basin (southern) is about $20 \mathrm{~m}$ deep (max. depth $=26 \mathrm{~m})$, about $8 \mathrm{~km}$ in length and about $3 \mathrm{~km}$ in width. The main basin (northern) is about $22 \times 2.5 \mathrm{~km}$ with steep lateral slopes (east, west) and a maximum depth of $137 \mathrm{~m}$. Across the transition from the southern into the northern basins, the water depth increases within $2.5 \mathrm{~km}$ from $26 \mathrm{~m}$ to $107 \mathrm{~m}$.

The major flow into Lake Zurich occurs longitudinally from the Linth River connecting Lake Walenstadt and the Upper Lake. These act as settling basins and, thus, the riverine input of allochthonous material into Lake Zurich is effectively entrapped in the Upper Lake. Therefore, riverine sediment inputs into the Lower Lake are low in summer, and the bulk of sediment particles derives from 
autochthonous processes. The riverine input of allochthonous material may be higher during circulation in winter. It is noted that the specific geomorphic situation make this lake ideal for investigating particle dynamics driven by in-lake processes and boundary effects.

\section{Methods}

Three moorings were established in a two-dimensional array (total of 8 sediment traps) along the longitudinal transect between April and October, 1989: Mooring A with 4 sediment traps at $40 \mathrm{~m}, 70 \mathrm{~m}, 100 \mathrm{~m}$ and $130 \mathrm{~m}$ water depth located at the deepest part of Lake Zurich (National Grid Reference co-ordinate: 687, 600/236, $200 ; 137 \mathrm{~m}$ water depth), mooring B with 3 sediment traps at $40 \mathrm{~m}, 70 \mathrm{~m}$ and $100 \mathrm{~m}$ water depth located at the bottom of the slope $(693,400 / 233,800 ; 100 \mathrm{~m}$ water depth) and mooring $C$ with one sediment trap at $40 \mathrm{~m}$ in the transitional area between the two basins $(694,600 / 232,600 ; 45-50 \mathrm{~m}$ water depth) (Fig. 1). The traps were deployed well below the thermocline $(10-15 \mathrm{~m})$ to record hypolimnetic particle fluxes. Note that short exposure time of the traps below the thermocline, low temperature $\left(\mathrm{T}=6^{\circ} \mathrm{C}\right)$ and minimal light and productivity minimise mineralisation of the sedimentary material and, thus, no additives were used for preservation. All traps were exchanged triweekly (i.e., every 21 days) between April and October. In addition, the $40 \mathrm{~m}$ and $130 \mathrm{~m}$ traps at station $\mathrm{A}$ were exchanged triweekly before and after the sampling campaign. Therefore, annual particle fluxes measured at station A can be compared with the data reported by Schuler et al. (1991).

Sediment traps, collection methods and treatment of the sediment trap material are described in Sturm et al. (1982) and Schuler et al. (1991). Sediment traps (20 cm diameter and $100 \mathrm{~cm}$ high) were deployed in duplicates at each water depth. The samples were stored at $4^{\circ} \mathrm{C}$ after recovery and combined into one mixed sample for further processing. Collected particle matter was freeze-dried and weighed. The dry weight of the particulate matter was corrected for the contribution of dissolved salts resulting from freeze-drying of supernatant water (estimate $=10 \%$ correction). Between 1 and 8 grams each were used for chemical and radiochemical analysis. Errors in particle flux were estimated to be less than $\pm 10 \%$ based on duplicate flux measurements.

\section{Chemical Analysis}

Wavelength dispersive X-ray fluorescence spectrometry (WD-XRF; Philips PW 1404) was used for multi-element analyses of the trap material. The method is nondestructive and requires no pre-treatment. Careful calibration was required due to the sensitivity of XRF to matrix variations in calcium carbonate, quartz, organic matter, manganese oxides and iron oxides. Calibrations were performed for a total of ten major and minor elements ( $\mathrm{Si}, \mathrm{Al}, \mathrm{Fe}, \mathrm{Mn}, \mathrm{Mg}, \mathrm{Ca}, \mathrm{Na}, \mathrm{K}, \mathrm{P}, \mathrm{S})$ and seven trace elements $(\mathrm{Ba}, \mathrm{Rb}, \mathrm{Sr}, \mathrm{Ti}, \mathrm{Zr}, \mathrm{Pb}, \mathrm{Zn})$ using 25 certified standards of sedimentary, soil and sewage sludge materials. Corrections for matrix effects were applied for each element on the basis of theoretical $\alpha$ correction factors evaluated for an 
average particle composition. For analysis, pressed powder pellets with a diameter of $20 \mathrm{~mm}$ and a thickness of $1-2 \mathrm{~mm}$ were prepared ( 0.5 to $1 \mathrm{~g}$ trap material) without any preparation additives.

Reproducibility of XRF was excellent (i. e., $\pm 1 \%$ ). Accuracy was less mainly due to variations in the matrix composition which caused uncertainties in the $\alpha$ correction factor for a given particle composition. Elements with high atomic numbers were less sensitive to matrix effects, whereas analytical errors were significant for lighter elements (e.g., $P$ and S). For all elements, uncertainties in the concentrations were estimated to be less than $\pm 10 \%$ based on the results of the standardisation, except those for P and S $(\leq \pm 20 \%)$.

Total carbon and nitrogen were measured with a CNS-Analyser (Carlo-Erba). The concentration of organic $\mathrm{C}$ was determined from the difference of total carbon and carbonate $\mathrm{C}$ evaluated from the calcium content of the particles $\left(=\right.$ TOT-C $\left.-\mathrm{CaCO}_{3}-\mathrm{C}\right)$.

\section{Results and Discussion}

\section{Sediment trap fluxes of settling material}

Sedimentary particle fluxes measured in the sediment traps between 20 April and 24 October, 1989, are listed in Table 1 and shown in Figure 2. Average fluxes are given as weighted mean values. Estimates of uncertainties are based on the error in particle flux measurements $( \pm 10 \%)$ and an additional analytical error of generally $\leq 10 \%$. In Figure 3, mass fluxes are depicted as weighted mean values for the entire sampling period.

Seasonal variations in mass fluxes reveal features typically observed for prealpine freshwater lakes, with a maximum in particle flux in July and August reflecting algael blooms and calcite precipitation (Fig. 2). Highest mass fluxes up to about $3.6 \mathrm{~g} \mathrm{~m}^{2} \mathrm{~d}^{-1}$ occurred at mooring $\mathrm{C}$, the station at the transition from the shallow to the deeper basin of Lower Lake Zurich (Table 1, Fig. 3). Fluxes were almost double

Table 1. Mass flux in sediment traps between 20 April and 24 October 1989

\begin{tabular}{|c|c|c|c|c|c|c|c|c|c|}
\hline \multicolumn{10}{|c|}{ Collection Period } \\
\hline Trap & $\begin{array}{l}\text { I } \\
20 \text { April- } \\
13 \text { May }\end{array}$ & $\begin{array}{l}\text { II } \\
13 \text { May- } \\
1 \text { June }\end{array}$ & $\begin{array}{l}\text { II } \\
1 \text { June- } \\
\text { 26 June }\end{array}$ & $\begin{array}{l}\text { IV } \\
26 \text { June- } \\
13 \text { July }\end{array}$ & $\begin{array}{l}\text { V } \\
13 \mathrm{July}- \\
3 \mathrm{Aug}\end{array}$ & $\begin{array}{l}\text { VI } \\
3 \text { Aug- } \\
24 \text { Aug }\end{array}$ & $\begin{array}{l}\text { VII } \\
24 \text { Aug- } \\
14 \text { Sep }\end{array}$ & $\begin{array}{l}\text { VIII } \\
14 \text { Sept- } \\
5 \text { Oct }\end{array}$ & $\begin{array}{l}\text { IX } \\
5 \text { Oct- } \\
24 \text { Oct }\end{array}$ \\
\hline A $40 \mathrm{~m}$ & 1.56 & 0.79 & 3.83 & 2.45 & 4.45 & 2.06 & 0.72 & 0.66 & 0.21 \\
\hline A $70 \mathrm{~m}$ & 1.51 & 1.24 & 4.67 & 3.63 & 5.68 & 2.47 & 0.78 & 0.56 & 0.37 \\
\hline A $100 \mathrm{~m}$ & 1.72 & 1.41 & 4.48 & 3.66 & 8.42 & 2.80 & 0.96 & 0.52 & 0.30 \\
\hline A $130 \mathrm{~m}$ & 2.05 & 1.40 & 4.11 & 3.35 & 3.24 & 1.84 & 0.67 & 0.56 & 0.54 \\
\hline B $40 \mathrm{~m}$ & 1.88 & 1.34 & 4.08 & 3.59 & 4.99 & 2.35 & 1.15 & 0.99 & 0.42 \\
\hline B $70 \mathrm{~m}$ & 1.72 & 1.51 & 4.43 & 2.74 & 5.48 & 3.49 & 1.11 & 1.00 & 0.33 \\
\hline B $100 \mathrm{~m}$ & 2.25 & 1.56 & 4.37 & 3.93 & 5.40 & 3.37 & 1.15 & 1.07 & 0.82 \\
\hline $\mathrm{C} 40 \mathrm{~m}$ & - & 1.45 & 4.20 & 5.28 & 7.06 & 4.62 & 1.70 & 1.80 & 1.63 \\
\hline
\end{tabular}

Units are $\mathrm{g} \mathrm{m}^{-2} \mathrm{~d}^{-1}$. Errors in fluxes are estimated to $\leq \pm 10 \%$ based on duplicate measurements. 


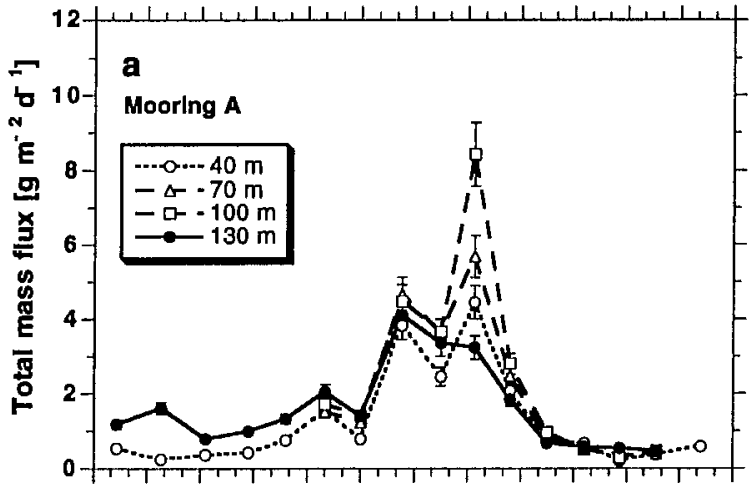

Jan Feb Mar Apr May Jun Jul Aug Sep Oct Nov Dec

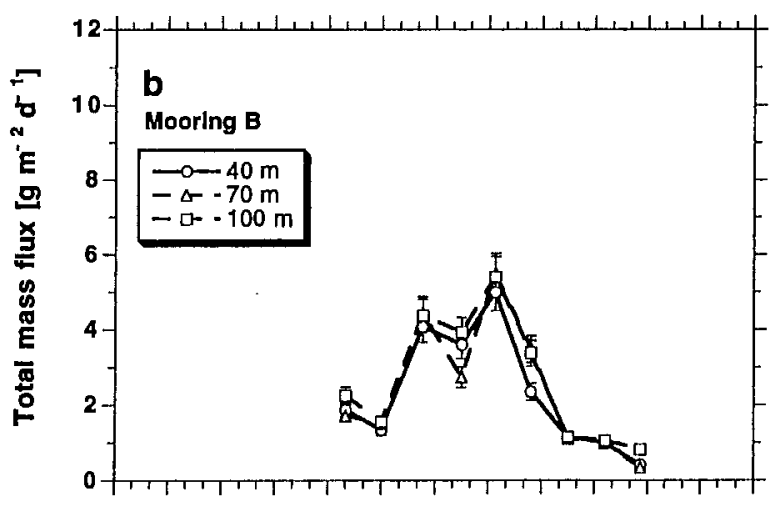

Jan Feb Mar Apr May Jun Jul Aug Sep Oct Nov Doc

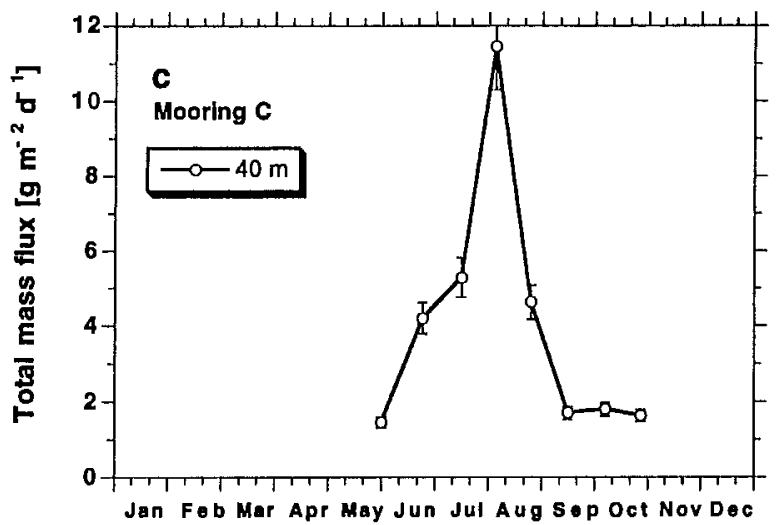

Figure 2. Seasonal variations in the particle fluxes at sampling sites A, B and C. At site A, the sediment traps at $40 \mathrm{~m}$ and $130 \mathrm{~m}$ water depth were exchanged triweekly between January and December, 1989. The sediment traps at $70 \mathrm{~m}$ and $130 \mathrm{~m}$ water depth as well as the the traps at sites $B$ and $C$ were deployed during summer stratification (site B: 20 April -24 October; site C: 13 May24 October) 


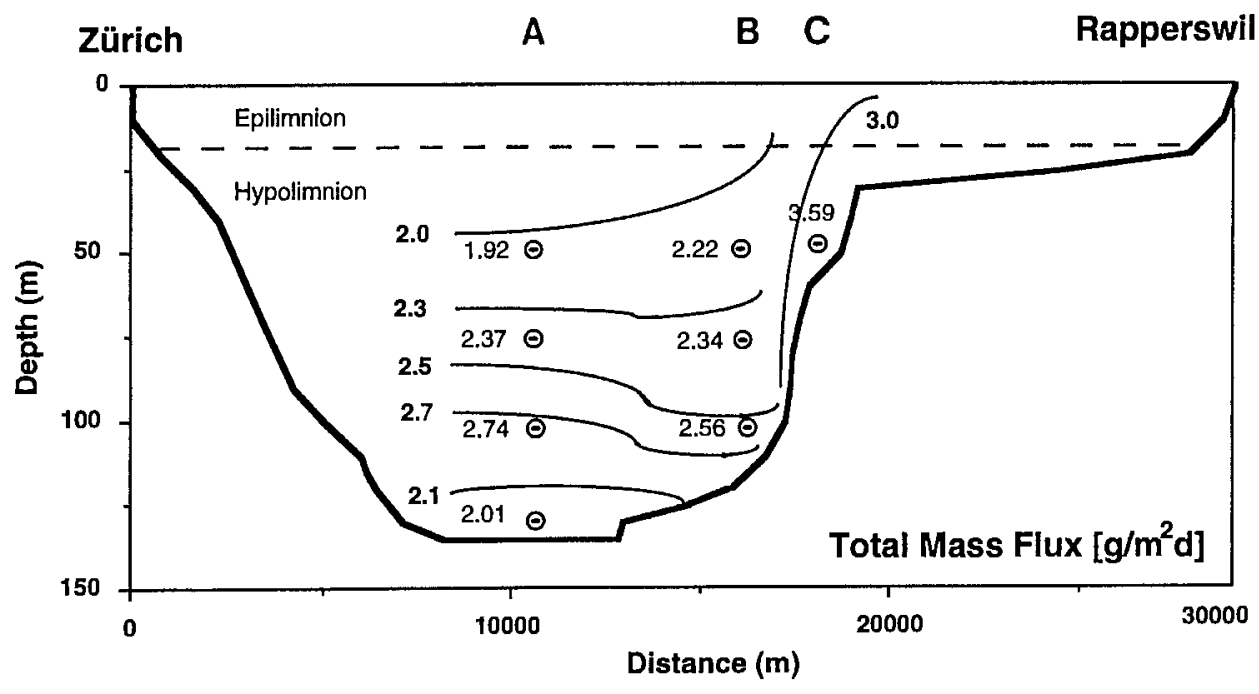

Figure 3. Time-weighted averages of particle fluxes in the sediment traps between 20 April24 October at sites A and B, and between 13 May and 24 October at site C

those for the same water depths in the main basin (mooring A). This increase may be due to enhanced primary production or horizontal sediment transport in the littoral zone. At mooring $B$, mass flux increased gradually with water depth from 2.22 to $2.56 \mathrm{~g} \mathrm{~m}^{2} \mathrm{~d}^{-1}$ (Table 1, Fig. 3). For most sampling intervals, the flux at station $B$ was substantially enhanced in the near-bottom sediment trap deployed at $100 \mathrm{~m}$ water depth (Table 1). Moreover, the peaks in mass flux occurred simultaneously in the near-surface and near-bottom traps at this station. At mooring A, significant variability in particle fluxes was observed (Fig. 2). Between 27 July and 3 August, a single event of increased sediment flux, which was not recorded at station B, was documented in the central part of the lake. This event corresponds to a maximum in the $\mathrm{CaCO}_{3}$ flux. However, during this and the subsequent collection period, the mass fluxes in near-bottom trap were only about $50 \mathrm{wt} . \%$ of those documented in the overlying traps. A re-evaluation of the experimental protocol indicated that experimental artefacts can be excluded. Hence, the lower average flux evaluated for the $130 \mathrm{~m}$ trap was the result of a significant reduction in mass flux observed between 27 July and 3 August (Fig. 3). A tentative explanation for incomplete flux measurements will be given in the following section. Note that average mass flux was higher in the near-bottom than in the overlying traps for the other collection periods (Table 1 ).

In a 5-year study of particle and radionuclide dynamics in Lake Zurich, Schuler et al. (1991) measured particle fluxes at station A using sediment traps deployed at $50 \mathrm{~m}$ and $130 \mathrm{~m}$ water depth. Summer averages for the period 1983-1987 were determined to be $2.63 \mathrm{~g} \mathrm{~m}^{-2} \mathrm{~d}^{-1}$ (50 m trap) and $2.93 \mathrm{~g} \mathrm{~m}^{-2} \mathrm{~d}^{-1}$ (130 m trap) (Schuler et al., 1991). During the summer 1989, the average particle fluxes in the $40 \mathrm{~m}$ and $130 \mathrm{~m}$ traps were $1.92 \mathrm{~g} \mathrm{~m}^{-2} \mathrm{~d}^{-1}$ and $2.01 \mathrm{~g} \mathrm{~m}^{-2} \mathrm{~d}^{-1}$, respectively. Annual fluxes in 1989 and for the period 1983 to 1987 were estimated to be $1.28 \mathrm{~g} \mathrm{~m}^{-2} \mathrm{~d}^{-1}$ and $1.86 \mathrm{~g} \mathrm{~m}^{-2} \mathrm{~d}^{-1}$, 
respectively, for the near-surface trap, and $1.60 \mathrm{~g} \mathrm{~m}^{-2} \mathrm{~d}^{-1}$ and $2.16 \mathrm{~g} \mathrm{~m}^{-2} \mathrm{~d}^{-1}$, respectively, for the near-bottom trap. Thus, at both water depths, summer and annual fluxes in 1989 were lower than the corresponding fluxes evaluated for the period 1983-1987. A comparison of inter-annual differences in sedimentation (see Table 2 in Schuler et al., 1991) indicates a continuous decrease in particle flux between 1983 and 1989, for reasons not yet known. It is believed that the low levels in the yearly primary production reached in the 1980s and indicated by a significant reduction in zooplankton biomass production (Zimmermann et al., 1992) gave rise to a reduction in the production of autochthonous $\mathrm{CaCO}_{3}$, the main contribution to mass flux. It should be noted that, due to conditions of low turbulence in the hypolimnion during summer stratification, the possibility of an experimental artefact caused by changes in the aspect ratio (cylinder height to diameter) of the sediment traps from 9:1 (1983-1987) to 5:1 (1989) can be excluded (Bloesch and Burns, 1980).

\section{Temporal and spatial variations in the composition of settling particles}

Results of the chemical analysis of the settling material are listed in Table 2. The concentration of an element is given as the mean value of all measurements for each trap, i.e., of a total of 9 samples. Uncertainties are based on standard deviations for a $95 \%$ confidence level. Measurements of organic C (Org-C), total N (TOT-N), P, $\mathrm{Ca}, \mathrm{Fe}, \mathrm{Mn}, \mathrm{Al}$ and $\mathrm{Si}$ concentrations were used to evaluate the composition of the settling matter. Previous studies showed that the settling material in Lake Zurich consists mainly of calcium carbonate, organic matter, iron oxides, manganese oxides and silicate minerals (Giovanoli et al., 1980; Sigg, 1985; Sigg et al., 1987). The major elements provide a measure of relative contributions of the different components to the particulate matter (Giovanoli et al., 1980; Sigg et al., 1987): C, N and P for biological material, $\mathrm{Ca}$ for calcium carbonate, Fe for iron oxides, Mn for manganese oxides, and $\mathrm{Al}$ and $\mathrm{Si}$ for silica (biogenic $\mathrm{SiO}_{2}$, quartz) and alumino silicates. Figures $4 \mathrm{a}$ and $\mathrm{b}$ showing the seasonal variation in the particle composition for two sediment traps at mooring A confirm earlier results (Sigg et al., 1987). To elucidate spatial variations in the particle composition, concentration ratios for organic C, calcium, iron and manganese were estimated by normalising the concentration of an element to the concentration measured on the settling material which was collected from the $40 \mathrm{~m}$ trap at station A. Changes in element concentrations of sedimentary material can then be expressed relative to the concentration of an element on the material collected by the sediment trap with maximum distance to the margin of the lake. The relative elemental content was obtained by averaging the concentration ratios over the entire period of sediment trap deployment:

$$
\text { relative element content }=\frac{\sum_{n=1}^{9}\left(\frac{c_{i, n}}{c_{A 40 m, n}}\right)}{n}
$$

where $c_{\mathrm{i}}$ and $\mathrm{c}_{\mathrm{A} 40 \text { In }}$ represent the concentrations of an element in sediment trap $\mathrm{i}$ ( $\mathrm{i}=\mathrm{A} 70 \mathrm{~m}, \mathrm{~A} 100 \mathrm{~m}, \mathrm{~A} 130 \mathrm{~m}, \mathrm{~B} 40 \mathrm{~m}, \mathrm{~B} 70 \mathrm{~m}, \mathrm{~B} 100 \mathrm{~m}, \mathrm{C} 40 \mathrm{~m}$ ) and the $40 \mathrm{~m}$ sediment trap at station $\mathrm{A}$, respectively, and $\mathbf{n}$ is the number of samples or triweekly 
Table 2. Element concentrations in trap material of Lake Zurich

\begin{tabular}{|c|c|c|c|c|c|c|c|c|c|c|}
\hline Trap & $\begin{array}{l}\text { Org-C } \\
{\left[\mathrm{mmol} \mathrm{g}^{-1}\right]}\end{array}$ & $\begin{array}{l}\text { TOT-N } \\
{\left[\mathrm{mmol} \mathrm{g}^{-1}\right]}\end{array}$ & $\begin{array}{l}\mathrm{P} \\
{\left[\mathrm{mmol} \mathrm{g}^{-1}\right]}\end{array}$ & $\begin{array}{l}\mathrm{Ca} \\
{\left[\mathrm{mmol} \mathrm{g}^{-1}\right]}\end{array}$ & $\begin{array}{l}\mathrm{Si} \\
{\left[\mathrm{mmol} \mathrm{g}^{-1}\right]}\end{array}$ & $\begin{array}{l}\mathrm{Al} \\
{\left[\mathrm{mmol} \mathrm{g}^{-1}\right]}\end{array}$ & $\begin{array}{l}\mathrm{Fe} \\
{\left[\mathrm{mmol} \mathrm{g}^{-1}\right]}\end{array}$ & $\begin{array}{l}\mathrm{Mn} \\
{\left[\mathrm{mmol} \mathrm{g}^{-1}\right]}\end{array}$ & $\begin{array}{l}\mathrm{Mg} \\
{\left[\mathrm{mmol} \mathrm{g}^{-1}\right]}\end{array}$ & $\begin{array}{l}\mathrm{K} \\
{\left[\mathrm{mmol} \mathrm{g}^{-1}\right]}\end{array}$ \\
\hline A $40 \mathrm{~m}$ & $4.2 \pm 0.7$ & $0.86 \pm 0.01$ & $0.04 \pm 0.01$ & $8.1 \pm 1.2$ & $2.5 \pm 0.4$ & $0.19 \pm 0.03$ & $0.07 \pm 0.01$ & $0.006 \pm 0.001$ & $0.14 \pm 0.02$ & $0.05 \pm 0.002$ \\
\hline A $70 \mathrm{~m}$ & $3.6 \pm 0.6$ & $0.76 \pm 0.01$ & $0.04 \pm 0.01$ & $8.2 \pm 1.2$ & $2.5 \pm 0.4$ & $0.19 \pm 0.03$ & $0.08 \pm 0.01$ & $0.013 \pm 0.002$ & $0.15 \pm 0.02$ & $0.05 \pm 0.002$ \\
\hline A $100 \mathrm{~m}$ & $3.7 \pm 0.6$ & $0.76 \pm 0.01$ & $0.04 \pm 0.01$ & $8.1 \pm 1.2$ & $2.5 \pm 0.4$ & $0.20 \pm 0.03$ & $0.09 \pm 0.01$ & $0.030 \pm 0.004$ & $0.15 \pm 0.02$ & $0.05 \pm 0.002$ \\
\hline A $130 \mathrm{~m}$ & $5.1 \pm 0.8$ & $0.95 \pm 0.01$ & $0.06 \pm 0.01$ & $7.0 \pm 1.0$ & $3.2 \pm 0.5$ & $0.25 \pm 0.03$ & $0.13 \pm 0.02$ & $0.360 \pm 0.052$ & $0.15 \pm 0.02$ & $0.06 \pm 0.003$ \\
\hline B $40 \mathrm{~m}$ & $4.7 \pm 0.7$ & $0.90 \pm 0.01$ & $0.04 \pm 0.01$ & $7.3 \pm 1.0$ & $3.3 \pm 0.5$ & $0.28 \pm 0.04$ & $0.11 \pm 0.02$ & $0.011 \pm 0.001$ & $0.16 \pm 0.02$ & $0.07 \pm 0.003$ \\
\hline B $70 \mathrm{~m}$ & $4.3 \pm 0.7$ & $0.83 \pm 0.01$ & $0.05 \pm 0.01$ & $7.3 \pm 1.0$ & $3.3 \pm 0.5$ & $0.28 \pm 0.04$ & $0.12 \pm 0.02$ & $0.019 \pm 0.003$ & $0.17 \pm 0.02$ & $0.07 \pm 0.003$ \\
\hline B $100 \mathrm{~m}$ & $5.0 \pm 0.8$ & $0.95 \pm 0.01$ & $0.06 \pm 0.01$ & $7.1 \pm 1.0$ & $3.5 \pm 0.5$ & $0.31 \pm 0.04$ & $0.14 \pm 0.02$ & $0.041 \pm 0.006$ & $0.17 \pm 0.02$ & $0.07 \pm 0.004$ \\
\hline \multirow[t]{2}{*}{$\mathrm{C} 40 \mathrm{~m}$} & $4.1 \pm 0.7$ & $0.81 \pm 0.01$ & $0.04 \pm 0.01$ & $7.9 \pm 1.1$ & $2.3 \pm 0.3$ & $0.28 \pm 0.04$ & $0.12 \pm 0.02$ & $0.015 \pm 0.002$ & $0.17 \pm 0.02$ & $0.06 \pm 0.003$ \\
\hline & $\begin{array}{l}\mathrm{Na} \\
{[\mu \mathrm{mol} \mathrm{g}-1]}\end{array}$ & $\begin{array}{l}\mathrm{Zr} \\
{\left[\mu \mathrm{mol} \mathrm{g}{ }^{-1}\right]}\end{array}$ & $\begin{array}{l}\mathrm{Ti} \\
{\left[\mu \mathrm{mol} \mathrm{g}^{-1}\right]}\end{array}$ & \multicolumn{2}{|c|}{$\begin{array}{l}\mathrm{Rb} \\
{\left[\mu \mathrm{mol} \mathrm{g}^{-1}\right]}\end{array}$} & $\begin{array}{l}\text { SI } \\
{\left[\mu \mathrm{mol} \mathrm{g}{ }^{-1}\right]}\end{array}$ & $\begin{array}{l}\mathrm{Ba} \\
{\left[\mu \mathrm{mol} \mathrm{g}{ }^{-1}\right]}\end{array}$ & $\begin{array}{l}\mathrm{S} \\
{\left[\mu \mathrm{mol} \mathrm{g}{ }^{-1}\right]}\end{array}$ & $\begin{array}{l}\mathrm{Zn} \\
{\left[\mu \mathrm{mol} \mathrm{g}{ }^{-1}\right]}\end{array}$ & $\begin{array}{l}\mathrm{Pb} \\
{\left[\mu \mathrm{mol} \mathrm{g}^{-1}\right]}\end{array}$ \\
\hline A $40 \mathrm{~m}$ & $37 \pm 3$ & $0.08 \pm 0.01$ & $5.8 \pm 1.0$ & \multicolumn{2}{|c|}{$0.15 \pm 0.02$} & $5.5 \pm 0.8$ & $1.0 \pm 0.2$ & $55 \pm 8$ & $1.9 \pm 0.3$ & $0.20 \pm 0.04$ \\
\hline A $70 \mathrm{~m}$ & $44 \pm 3$ & $0.09 \pm 0.02$ & $5.6 \pm 1.0$ & \multirow{2}{*}{\multicolumn{2}{|c|}{$\begin{array}{l}0.14 \pm 0.02 \\
0.14 \pm 0.02\end{array}$}} & $5.7 \pm 0.8$ & $1.1 \pm 0.2$ & $58 \pm 9$ & $1.9 \pm 0.3$ & $0.20 \pm 0.04$ \\
\hline A $100 \mathrm{~m}$ & $44 \pm 3$ & $0.08 \pm 0.01$ & $6.1 \pm 1.0$ & & & \multirow{2}{*}{$\begin{array}{l}5.6 \pm 0.8 \\
5.3 \pm 0.8\end{array}$} & \multirow{2}{*}{$\begin{array}{l}1.3 \pm 0.2 \\
2.9 \pm 0.4\end{array}$} & $57 \pm 9$ & \multirow{2}{*}{$\begin{array}{l}2.0 \pm 0.3 \\
3.0 \pm 0.5\end{array}$} & \multirow{2}{*}{$\begin{array}{l}0.20 \pm 0.04 \\
0.26 \pm 0.05\end{array}$} \\
\hline A $130 \mathrm{~m}$ & $49 \pm 4$ & $0.13 \pm 0.02$ & $7.1 \pm 1.3$ & $0.19 \pm 0.03$ & $5.3=$ & & & $68 \pm 10$ & & \\
\hline B $40 \mathrm{~m}$ & $46 \pm 3$ & $0.13 \pm 0.02$ & $8.6 \pm 1.5$ & $0.21 \pm 0.04$ & & $5.3 \pm 0.8$ & $1.1 \pm 0.2$ & $61 \pm 9$ & $2.1 \pm 0.3$ & $0.23 \pm 0.05$ \\
\hline B $70 \mathrm{~m}$ & $49 \pm 4$ & $0.15 \pm 0.02$ & $8.8 \pm 1.5$ & $0.21 \pm($ & $5.4=$ & 0.8 & \pm 0.2 & $63 \pm 9$ & $2.3 \pm 0.3$ & $0.22 \pm 0.05$ \\
\hline B $100 \mathrm{~m}$ & $48 \pm 3$ & $0.15 \pm 0.03$ & $9.4 \pm 1.7$ & $0.23 \pm$ & $5.3=$ & 0.8 & \pm 0.3 & $64 \pm 10$ & $2.9 \pm 0.4$ & $0.25 \pm 0.05$ \\
\hline $\mathrm{C} 40 \mathrm{~m}$ & $41 \pm 3$ & $0.13 \pm 0.02$ & $8.8 \pm 1.5$ & $0.19 \pm$ & $5.5=$ & 0.8 & \pm 0.2 & $55 \pm 8$ & $1.8 \pm 0.3$ & $0.25 \pm 0.05$ \\
\hline
\end{tabular}



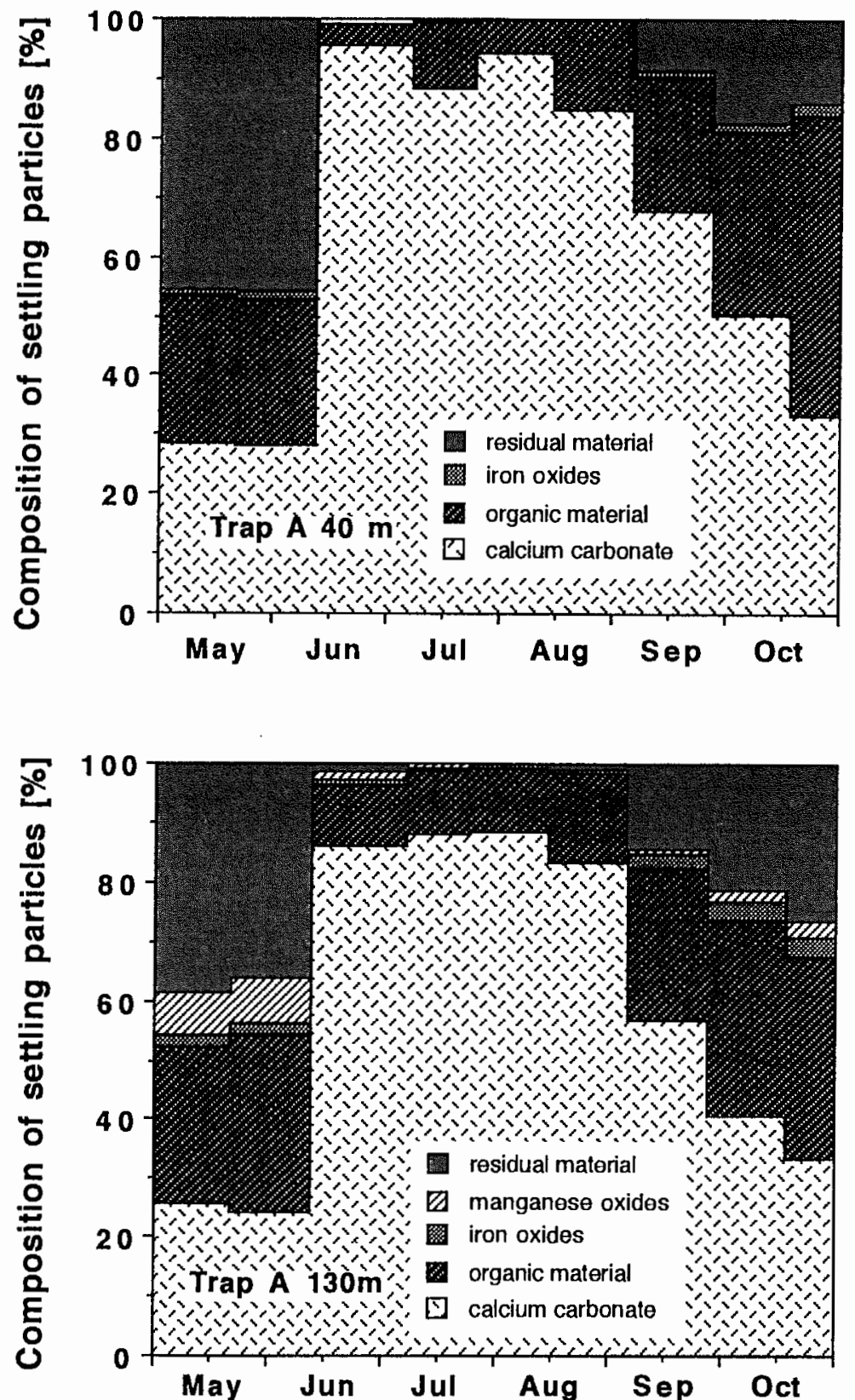

Figure 4. Seasonal variations in the composition of settling material collected from the $40 \mathrm{~m}$ and the $130 \mathrm{~m}$ sediment trap at site A 
deployment periods ( $\mathrm{n}=1$ to 9 ), respectively. In Figures $5 \mathrm{a}-\mathrm{f}$, the relative element contents of $\mathrm{Ca}$ (calcium carbonate), organic $\mathrm{C}$ (organic matter), $\mathrm{Fe}$ (iron oxides) and $\mathrm{Mn}$ (manganese oxides), $\mathrm{Si}$ (silica, quartz and alumino silicates) and $\mathrm{Al}$ (alumino silicates) on settling material are displayed.

Calcium carbonate: The fraction of $\mathrm{CaCO}_{3}$ ranged from 25 to $31 \%$ by dry weight of the settling material at the beginning of the stratification period, and up to 89 or $95 \mathrm{wt}$. \% , respectively, during the summer maximum in July and August (Figs. 4a and $b$ ). The maximum indicates $\mathrm{CaCO}_{3}$ precipitation in the summer epilimnion due to a $\mathrm{pH}$ increase ( $\mathrm{pH} 8.2$ to 8.5 ) caused by photosynthetic activity (Zimmermann et al., 1992). Figure 5a shows a rather uniform relative calcium content of the settling material regardless of the location of the traps in the lake. The trend to lower concentrations towards the margin of Lower Lake Zurich (e.g., mooring B and $130 \mathrm{~m}$ trap at mooring $\mathrm{A}$ ) as indicated in Figure $5 \mathrm{a}$ is not significant, given the uncertainties on the measurements.

Organic matter: The organic matter content of settling particles varied between 4 and $50 \mathrm{wt} .-\%$ over the period of investigation (Figs. $4 \mathrm{a}$ and b). Figure $5 \mathrm{~b}$ shows that the relative organic $C$ content tends to increase towards the margin of the lake, i.e. from mooring $\mathrm{A}$ to $\mathrm{B}$, and with depth at mooring $\mathrm{A}$. Organic $\mathrm{C}$, total $\mathrm{N}$ and total $P$ data were used to estimate the composition of organic matter (correlation coefficients $\mathrm{R} \geq 0.93$; Table 4 ). The average composition of the biological material was determined from the slopes of the regression lines to be $\left(\mathrm{CH}_{2} \mathrm{O}\right)_{95}\left(\mathrm{NH}_{3}\right)_{18} \mathrm{HPO}_{4}$ using the complete data set. The stoichiometric composition given here is comparable with results reported earlier for Lake Zurich, i.e., $\left(\mathrm{CH}_{2} \mathrm{O}\right)_{106}\left(\mathrm{NH}_{3}\right)_{16} \mathrm{HPO}_{4}$ given by Giovanoli et al. (1980), $\left(\mathrm{CH}_{2} \mathrm{O}\right)_{113}\left(\mathrm{NH}_{3}\right)_{15} \mathrm{HPO}_{4}$ published by Sigg (1985), and $\left(\mathrm{CH}_{2} \mathrm{O}\right)_{97}\left(\mathrm{NH}_{3}\right)_{16} \mathrm{HPO}_{4}$ reported by Sigg et al. (1987). However, a detailed analysis of the stoichiometric factors reveals that the mean $\mathrm{C}: \mathrm{P}$ and $\mathrm{N}: \mathrm{P}$ ratios varies considerably. Lowest $\mathrm{C}: \mathrm{P}$ ratios were observed between 20 April and 13 May, 1 June and 26 June and 5 October and 24 October. Moreover, the C : P ratio decreases with water depth. C : P ratios in the settling particles collected at $40 \mathrm{~m}$ depth range from $80-150$, exceeding Redfield ratios $(C: P=106)$ in most of the samples. Low ratios of 55-110 were determined for the settling material entrapped at $100 \mathrm{~m}$ and $130 \mathrm{~m}$ depth. Limitation of $P$ supply to algae in the top water layers and an increase in the bacterial content with depth, which store significantly more $\mathrm{P}$ than algae, may account for the depth dependence of the $\mathrm{C}: \mathrm{P}$ ratio (Gächter and Bloesch, 1985). The $\mathrm{N}: \mathrm{P}$ ratios of the settling material ranged from 11 to 31 over the period of investigation with an average $\mathrm{N}: \mathrm{P}$ ratio of $18 \pm 2$. The value is typical for mesotrophic lakes with nutrient sources from urban runoff or export from agricultural watersheds (Downing and Cauley, 1992). In addition, the ratio was dependent on the water depth, i.e., 16 to 31 at $40 \mathrm{~m}$ depth and 12 to 22 below $100 \mathrm{~m}$ depth, presumably due to the conversion of organically bound $\mathrm{N}$ into gaseous and inorganic $\mathrm{N}$ species by microbial nitrification and denitrification processes (Höhener and Gächter, 1993).

Iron oxides: Iron oxides most likely present as amorphous FeOOH (Giovanoli et al., 1980) could originate from effluents of sewage treatment plants, from soil par- 
Relative Ca content

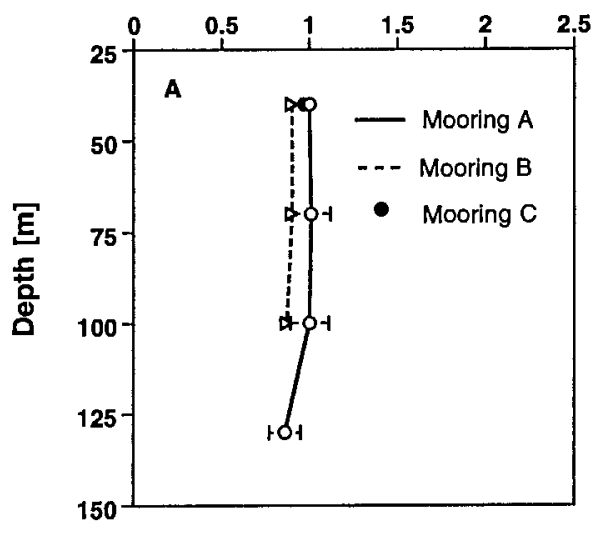

Relative Fe content

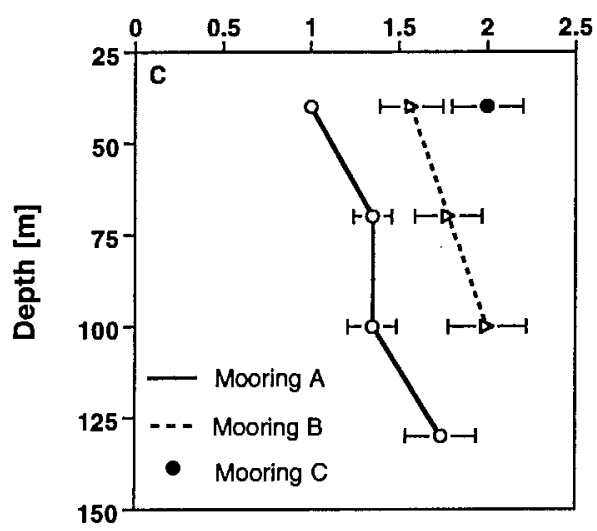

Relative Si content

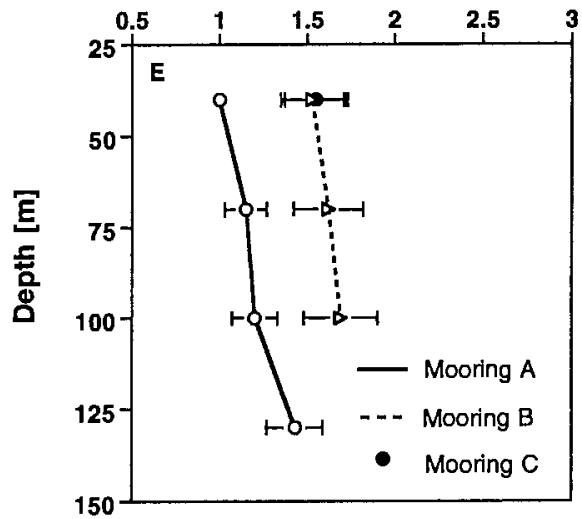

Relative organic $\mathbf{C}$ content

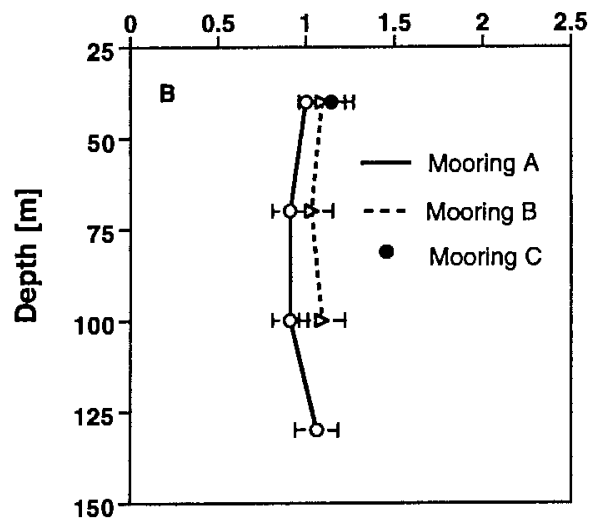

Relative Mn content

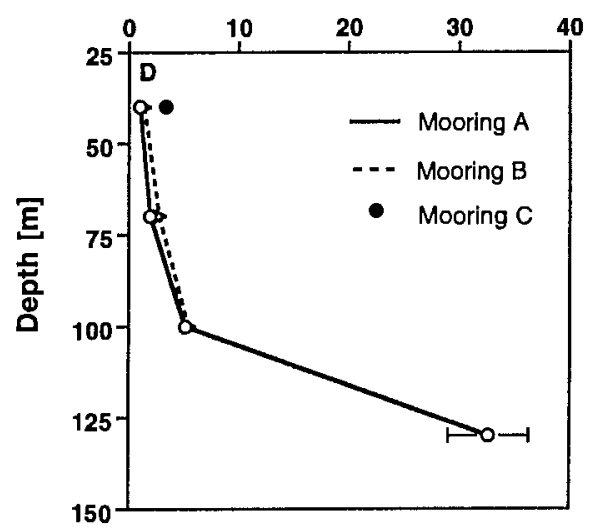

Relative Al content

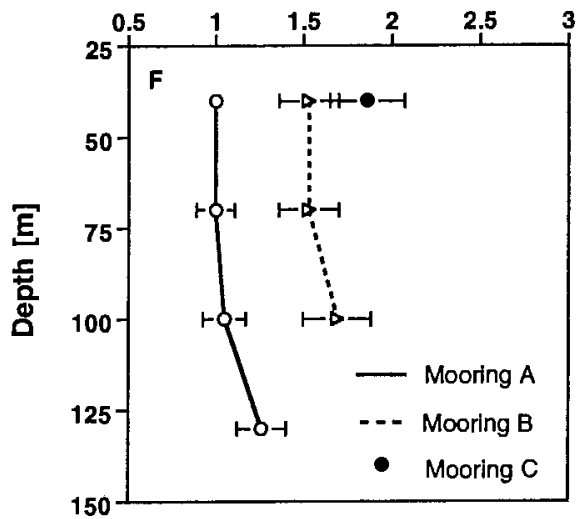

Figure 5a-f. Relative element content of A) Ca, B) organic C, C) Fe, D) Mn, E) Si and F) Al determined for settling material. Error limits denote the $95 \%$ confidence interval 
Table 3. Element fluxes in trap material of Lake Zurich in $\left[\mathrm{mmol} \mathrm{m}^{-2} \mathrm{~d}^{-1}\right]$ (upper row) and $\left[\mu \mathrm{mol} \mathrm{m} \mathrm{m}^{-2} \mathrm{~d}^{-1}\right]$ (lower row)

\begin{tabular}{|c|c|c|c|c|c|c|c|c|c|c|}
\hline Trap & $\begin{array}{c}\text { Org-C } \\
{\left[\mathrm{mmol} \mathrm{m}^{-2} \mathrm{~d}^{-1}\right]}\end{array}$ & TOT-N & $\mathrm{P}$ & $\mathrm{Ca}$ & $\mathrm{Si}$ & $\mathrm{Al}$ & $\mathrm{Fe}$ & $\mathrm{Mn}$ & $\mathrm{Mg}$ & $\mathrm{K}$ \\
\hline A $40 \mathrm{~m}$ & $8.1 \pm 1.0$ & $1.64 \pm 0.09$ & $0.07 \pm 0.01$ & $15.5 \pm 2.3$ & $4.9 \pm 0.7$ & $0.37 \pm 0.06$ & $0.14 \pm 0.02$ & $0.012 \pm 0.001$ & $0.27 \pm 0.04$ & $0.09 \pm 0.01$ \\
\hline A $70 \mathrm{~m}$ & $8.4 \pm 1.1$ & $1.81 \pm 0.10$ & $0.09 \pm 0.02$ & $19.4 \pm 2.9$ & $5.8 \pm 0.8$ & $0.46 \pm 0.07$ & $0.18 \pm 0.03$ & $0.032 \pm 0.004$ & $0.35 \pm 0.05$ & $0.11 \pm 0.02$ \\
\hline A $100 \mathrm{~m}$ & $10.0 \pm 1.3$ & $2.08 \pm 0.11$ & $0.12 \pm 0.02$ & $22.2 \pm 3.4$ & $6.8 \pm 1.0$ & $0.57 \pm 0.07$ & $0.25 \pm 0.04$ & $0.081 \pm 0.010$ & $0.40 \pm 0.06$ & $0.13 \pm 0.02$ \\
\hline A $130 \mathrm{~m}$ & $10.2 \pm 1.2$ & $1.91 \pm 0.10$ & $0.12 \pm 0.02$ & $14.1 \pm 2.1$ & $6.3 \pm 1.0$ & $0.53 \pm 0.08$ & $0.25 \pm 0.04$ & $0.721 \pm 0.106$ & $0.30 \pm 0.05$ & $0.12 \pm 0.02$ \\
\hline B $40 \mathrm{~m}$ & $10.5 \pm 1.2$ & $2.00 \pm 0.11$ & $0.10 \pm 0.02$ & $16.2 \pm 2.5$ & $7.4 \pm 1.1$ & $0.65 \pm 0.09$ & $0.23 \pm 0.03$ & $0.024 \pm 0.003$ & $0.36 \pm 0.05$ & $0.15 \pm 0.02$ \\
\hline B $70 \mathrm{~m}$ & $10.1 \pm 1.2$ & $1.93 \pm 0.10$ & $0.11 \pm 0.02$ & $17.1 \pm 2.6$ & $7.6 \pm 1.1$ & $0.69 \pm 0.10$ & $0.27 \pm 0.04$ & $0.044 \pm 0.006$ & $0.39 \pm 0.06$ & $0.16 \pm 0.02$ \\
\hline B $100 \mathrm{~m}$ & $12.7 \pm 1.5$ & $2.43 \pm 0.13$ & $0.15 \pm 0.02$ & $18.1 \pm 2.7$ & $8.9 \pm 1.2$ & $0.83 \pm 0.12$ & $0.36 \pm 0.05$ & $0.105 \pm 0.016$ & $0.42 \pm 0.06$ & $0.19 \pm 0.03$ \\
\hline \multirow[t]{2}{*}{ C $40 \mathrm{~m}$} & $14.7 \pm 1.8$ & $2.90 \pm 0.17$ & $0.16 \pm 0.03$ & $28.2 \pm 5.2$ & $8.3 \pm 1.2$ & $1.07 \pm 0.15$ & $0.41 \pm 0.06$ & $0.053 \pm 0.007$ & $0.59 \pm 0.09$ & $0.23 \pm 0.04$ \\
\hline & $\begin{array}{l}\mathrm{Na} \\
{\left[\mu \mathrm{mol} \mathrm{m}{ }^{-2} \mathrm{~d}^{-1}\right]}\end{array}$ & $\mathrm{Zr}$ & $\mathrm{Ti}$ & $\mathrm{Rb}$ & \multicolumn{2}{|r|}{$\mathrm{Sr}$} & $\mathrm{Ba}$ & $S$ & $\mathrm{Zn}$ & $\mathrm{Pb}$ \\
\hline A $40 \mathrm{~m}$ & $70 \pm 10$ & $0.16 \pm 0.02$ & $11.1 \pm 1.5$ & \multicolumn{2}{|c|}{$0.28 \pm 0.04$} & $10.6 \pm 1.6$ & $1.9 \pm 0.3$ & $104 \pm 18$ & $3.7 \pm 0.6$ & $0.38 \pm 0.07$ \\
\hline A $70 \mathrm{~m}$ & $105 \pm 16$ & $0.22 \pm 0.03$ & $13.4 \pm 1.9$ & \multicolumn{2}{|c|}{$0.33 \pm 0.05$} & $13.4 \pm 1.9$ & $2.5 \pm 0.4$ & $137 \pm 23$ & $4.5 \pm 0.7$ & $0.47 \pm 0.08$ \\
\hline A $100 \mathrm{~m}$ & $121 \pm 18$ & $0.21 \pm 0.03$ & $16.7 \pm 2.3$ & \multirow{2}{*}{\multicolumn{2}{|c|}{$0.38 \pm 0.06$}} & $15.3 \pm 2.2$ & $3.4 \pm 0.5$ & $157 \pm 27$ & $5.4 \pm 0.8$ & $0.56 \pm 0.10$ \\
\hline A $130 \mathrm{~m}$ & $98 \pm 14$ & $0.25 \pm 0.04$ & $15.4 \pm 2.1$ & & & $10.7 \pm 1.5$ & $5.9 \pm 0.9$ & $137 \pm 23$ & \multirow{2}{*}{$\begin{array}{l}6.1 \pm 0.9 \\
4.7+0.7\end{array}$} & $0.52 \pm 0.09$ \\
\hline B $40 \mathrm{~m}$ & $101 \pm 15$ & $0.28 \pm 0.04$ & $19.0 \pm 2.5$ & \multicolumn{2}{|c|}{$0.46 \pm 0.06$} & $11.8 \pm 1.6$ & $2.4 \pm 0.4$ & $135 \pm 23$ & & $0.52 \pm 0.09$ \\
\hline B 70m & $114 \pm 17$ & $0.34 \pm 0.04$ & $20.3 \pm 2.7$ & \multicolumn{2}{|c|}{$0.49 \pm 0.07$} & $12.6 \pm 1.8$ & $2.9 \pm 0.4$ & $147 \pm 26$ & $5.3 \pm 0.8$ & $0.52 \pm 0.09$ \\
\hline B $100 \mathrm{~m}$ & $123 \pm 19$ & $0.37 \pm 0.05$ & $24.0 \pm 3.3$ & \multicolumn{2}{|c|}{$0.59 \pm 0.08$} & $13.5 \pm 1.9$ & $4.2 \pm 0.8$ & $164 \pm 28$ & $7.5 \pm 1.1$ & $0.64 \pm 0.12$ \\
\hline $\mathrm{C} 40 \mathrm{~m}$ & $144 \pm 22$ & $0.47 \pm 0.06$ & $31.7 \pm 4.2$ & \multicolumn{2}{|c|}{$0.70 \pm 0.10$} & $19.8 \pm 2.8$ & $4.2 \pm 0.8$ & $198 \pm 29$ & $6.4 \pm 0.9$ & $0.88 \pm 0.17$ \\
\hline
\end{tabular}


ticles or from resuspended sedimentary material (Sigg et al., 1987). Iron oxides contributed between 0.3 and $6.6 \mathrm{wt} . \%$ to the settling material (Figs. $4 \mathrm{a}$ and b). In the traps at station $\mathrm{A}$ and $\mathrm{B}$, maximum contents of iron oxides were found to range between 2.0 and $3.5 \mathrm{wt} .-\%$. However, the highest contents were measured on the particles at station $C$ (maximum $6.6 \%$ ), i.e., the sediment traps deployed at $40 \mathrm{~m}$ in the transitional area between the two basins. Figure $5 \mathrm{c}$ shows an accumulation of iron on the settling material towards the margin of the lake indicating a nearshore Fe source. The enhanced iron content can be explained by resuspension of sedimentary material in the shallow basin and particle focusing towards the centre of Lower Lake Zurich.

Manganese oxides: Managanese contents of less than $0.2 \mathrm{wt} . \%$ were determined in the traps deployed in the upper water column. A slight enrichment was noted in the near-bottom trap at station B $(0.4 \mathrm{wt} . \mathrm{\%})$, but reached more than an order of magnitude ( $3 \mathrm{wt} .-\%)$ in the near-bottom trap at station A (Fig. $5 \mathrm{~d}$ ). These results are consistent with Sigg et al. (1987) and indicate that the manganese concentrations in the deeper water layers and on settling particles are strongly controlled by redox conditions occurring at the sediment-water interface.

Silica and alumino silicate fraction: The weight content of silica and alumino silicates in settling particles was estimated by:

$$
\text { Residual }=\text { total mass }-\sum \text { (organic material }+\mathrm{CaCO}_{3}+\mathrm{FeOOH}+\mathrm{MnO}_{2} \text { ) }
$$

This residual fraction consisting of quartz, biogenic $\mathrm{SiO}_{2}$ and alumino silicates (e.g., feldspars, micas, etc.) represented less than $1 \mathrm{wt} . \%$ of the trap material during maximum mass flux in summer (Figs. $4 \mathrm{a}$ and b). Higher relative amounts were observed in late summer, i.e., up to $20 \%$, and in winter and spring, i.e., between $35 \%$ and $45 \%$.

Figures $5 \mathrm{e}$ and $\mathrm{f}$ show the relative $\mathrm{Al}$ and $\mathrm{Si}$ contents of the settling material. $\mathrm{Al}$ and $\mathrm{Si}$ were enriched in the trapped material towards the margin of the lake. The higher Al content of the particles collected at site $\mathrm{C}$ indicates a lateral input flux of Al rich material (e.g., alumino silicates) from the shallow into the main basin of Lower Lake Zurich. The plume of resuspended Al silicates was also recorded at station $\mathrm{B}$ as well as in the $130 \mathrm{~m}$ trap at station $\mathrm{A}$. By contrast, the flux of resuspended particles had no significant effect on the relative Si content of the sedimentary material collected at station C (Fig. 5e). Thus, the Si budget appears to have been controlled by biogenic silica during stratification of Lake Zurich. Increasing Si contents in shoreward direction, i.e., at station $\mathrm{B}$ and $\mathrm{C}$, indicate that the spring bloom of diatoms preferentially occurred in the nearshore areas of the lake. Lateral transport of biogenic silica may account for increasing Si contents on the sedimentary material with depth. Note that the $\mathrm{Al}: \mathrm{Si}$ ratio of the settling material was not constant over the period of investigation. Three distinct periods can be distinguished (Fig. 6): 1) high particulate Si contents were found during the spring bloom of diatoms (April to June) with $\mathrm{Si}$ : Al ratios ranging from 16-32:1,2) a Si: Al ratio of about 10:1 was determined for the summer maximum (July to August), and 3 ) the $\mathrm{Si}$ : Al ratio reached a minimum of only $4.5: 1$ at the end of the stratification (August to October). High Si : Al ratios coinciding with low Si and Al concentrations indi- 


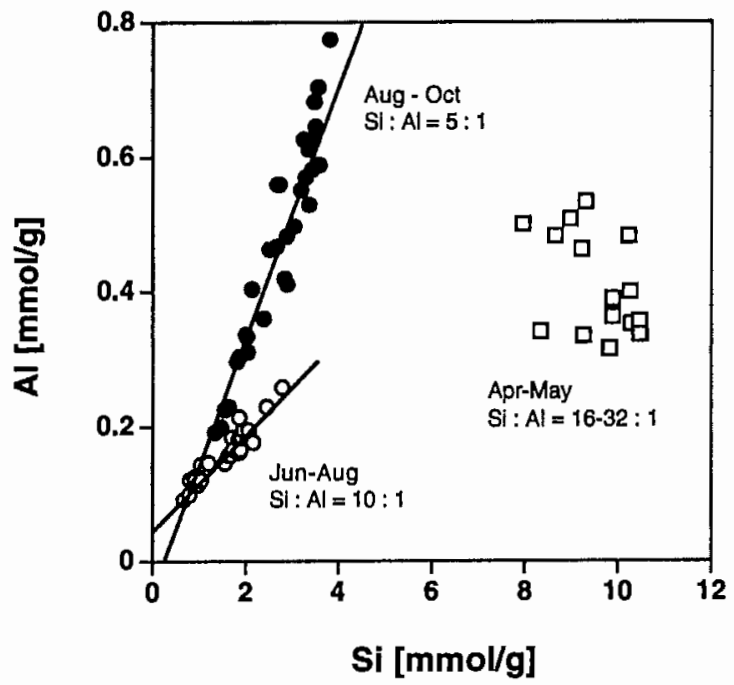

Figure 6. A plot of Al versus $\mathrm{Si}$ concentrations of settling particles showing three periods of different $\mathrm{Al}$ : Si stoichiometries

cate the presence of biogenic $\mathrm{SiO}_{2}$, which was substantially diluted by $\mathrm{CaCO}_{3}$ during the summer maximum. Monitoring of phytoplankton biomass in Lake Zurich in 1989 (Zimmermann et al., 1992; Zimmermann, 1993) support our interpretation of the data: The maximum bloom of Bacillariophyacea (diatoms) was observed in April and May. It confirms that two distinct $\mathrm{Si}$ fractions contribute to the total $\mathrm{Si}$ concentration of settling particles: Biogenic $\mathrm{Si}$ as $\mathrm{SiO}_{2}$ contribution from the spring bloom of diatoms (Fig. 6), and mineralic Si as quartz and alumino silicates. Since the riverine input of allochthonous material is of minor importance during the stratification of the lake basins, we infer that quartz and alumino silicates are of in-lake origin.

The elemental composition of the alumino silicate fraction was determined as follows: We assume that $\mathrm{Si}, \mathrm{Al}, \mathrm{Mg}, \mathrm{K}, \mathrm{Na}$, and the trace elements $\mathrm{Rb}, \mathrm{Ba}, \mathrm{Ti}$ and $\mathrm{Zr}$ are co-crystallised elements in the rock-forming minerals. The assumption is justified based on the available correlations between major and trace elements (Table 4). The concentrations of $\mathrm{K}, \mathrm{Rb}$ and $\mathrm{Ti}$ in the settling material correlate very well with the $\mathrm{Al}$ concentration of the samples (correlation coefficients $\mathrm{r}>0.97$; Table 4). The correlation of $\mathrm{Al}$ with $\mathrm{Mg}, \mathrm{Na}$ and $\mathrm{Zr}$ concentrations is poorer (Table 4), although statistically still significant. Mainly for the late summer samples, the high significance of the correlations indicates a close association of the elements with the silica and alumino silicate fraction of the sedimentary material. We further assume that the $\mathrm{Si}: \mathrm{Al}$ ratio determined for the late summer samples (August to October) is representative of the $\mathrm{Si}$ : Al stoichiometry of the alumino silicate fraction (Fig. 6). On these assumptions, the stoichiometry of the elements $\mathrm{Si}, \mathrm{Al}, \mathrm{Mg}$, $\mathrm{K}$ and $\mathrm{Na}$ results to $\mathrm{Al}_{7} \mathrm{Si}_{35} \mathrm{Mg}_{2.9} \mathrm{~K}_{1.8} \mathrm{Na}$ using the coefficients obtained from the slopes of the regression lines. Including the biogenic Si fraction, the stoichiometry of the mineralic fraction can then be given to (bio-SiO $)_{2-167}\left(\mathrm{Al}_{7} \mathrm{Si}_{35} \mathrm{Mg}_{2.9} \mathrm{~K}_{1.8} \mathrm{Na}\right)$. 
Table 4. Correlation of the elements in the trap material

\begin{tabular}{|c|c|c|c|c|c|c|c|c|c|c|c|c|c|c|c|c|}
\hline & $\mathrm{C}$ & $\mathrm{N}$ & $\mathrm{P}$ & $\mathrm{Si}^{3)}$ & $\mathrm{Ca}$ & $\mathrm{Al}$ & $\mathrm{Fe}$ & $\mathrm{Mn}$ & $\mathrm{Mg}$ & $\mathrm{Na}$ & $\mathrm{K}$ & $\mathrm{Ti}$ & $S$ & $\mathrm{Zr}$ & $\mathrm{Sr}$ & $\mathrm{Rb}$ \\
\hline C & & & & & & & & & & & & & & & & \\
\hline $\mathrm{N}$ & 0.99 & & & & & & & & & & & & & & & \\
\hline $\mathrm{P}$ & 0.94 & 0.93 & & & & & & & & & & & & & & \\
\hline $\mathrm{Si}$ & 0.82 & 0.81 & 0.77 & & & & & & & & & & & & & \\
\hline $\mathrm{Ca}$ & neg 1$)$ & neg & neg & neg & & & & & & & & & & & & \\
\hline Al & 0.83 & 0.82 & 0.82 & 0.95 & neg & & & & & & & & & & & \\
\hline $\mathrm{Fe}$ & 0.87 & 0.86 & 0.89 & 0.91 & neg & 0.96 & & & & & & & & & & \\
\hline $\mathrm{Mn}$ & $\mathrm{no}^{2)}$ & no & no & no & no & no & no & & & & & & & & & \\
\hline $\mathrm{Mg}$ & 0.73 & 0.72 & 0.69 & 0.77 & neg & 0.76 & 0.70 & no & & & & & & & & \\
\hline $\mathrm{Na}$ & 0.62 & 0.63 & 0.64 & 0.70 & neg & 0.64 & 0.60 & no & 0.93 & & & & & & & \\
\hline $\mathrm{K}$ & 0.90 & 0.89 & 0.85 & 0.95 & neg & 0.97 & 0.93 & no & 0.74 & 0.75 & & & & & & \\
\hline $\mathrm{Ti}$ & 0.85 & 0.84 & 0.80 & 0.95 & neg & 0.99 & 0.95 & no & 0.75 & 0.70 & 0.97 & & & & & \\
\hline$S$ & 0.86 & 0.85 & 0.81 & 0.78 & neg & 0.66 & 0.77 & no & 0.50 & 0.47 & 0.64 & 0.65 & & & & \\
\hline $\mathrm{Zr}$ & 0.71 & 0.71 & 0.67 & 0.85 & neg & 0.89 & 0.85 & no & 0.68 & 0.63 & 0.86 & 0.88 & 0.59 & & & \\
\hline $\mathrm{Sr}$ & neg & neg & neg & neg & 0.87 & neg & neg & no & neg & neg & neg & neg & neg & neg & & \\
\hline $\mathrm{Rb}$ & 0.86 & 0.85 & 0.81 & 0.95 & neg & 0.98 & 0.94 & no & 0.74 & 0.69 & 0.97 & 0.99 & 0.65 & 0.87 & neg & \\
\hline $\mathrm{Ba}$ & 0.48 & 0.47 & 0.45 & 0.70 & neg & 0.52 & 0.65 & 4) & 0.40 & 0.37 & 0.50 & 0.51 & 0.35 & 0.46 & neg & 0.51 \\
\hline
\end{tabular}

Coefficients $R \geq 0.4$ denote statistically significant correlation of the two elements at $99.9 \%$ confidence level $(n=63, p \leq 0.001)$.

1) Negative correlation.

2) No statistically significant correlation.

3) Only samples collected between Jun 1 and Oct $24(n=48)$.

4) Correlation of $\mathrm{Mn}$ and $\mathrm{Ba}$ see text.

We anticipate that the overall stoichiometry of the major elements of the mineralic fraction $\left(\mathrm{Al}_{7} \mathrm{Si}_{35} \mathrm{Mg}_{2.9} \mathrm{~K}_{1.8} \mathrm{Na}\right)$ represents an assemblage of mineral phases. Studies by Giovanoli et al. (1980) and Grütter et al. (1990) indicate that quartz, pyllosilicates (i.e., illite, biotite and chlorite) and tectosilicates (i.e., albite and $\mathrm{K}$-feldspars) present in the drainage basin of Lake Zurich are the dominating Si-containing mineral phases of the settling material. Thus, the stoichiometric ratio of the main elements associated with the silicate fraction $\left(\mathrm{Al}_{7} \mathrm{Si}_{35} \mathrm{Mg}_{2.9} \mathrm{~K}_{1.8} \mathrm{Na}\right)$ represents a synthetic mineral assemblage containing about $1 \mathrm{~mol}$ of albite $\left(\mathrm{NaAlSi}_{3} \mathrm{O}_{8}\right), 0.83$ moles of K-feldspars $\left(\mathrm{KAISi}_{3} \mathrm{O}_{8}\right), 0.97$ moles of iron-free mica $\left(\mathrm{KMg}_{3}(\mathrm{OH})_{2} \mathrm{AlSi}_{3} \mathrm{O}_{10}\right), 4.2$ moles of aluminium hydroxide $\left(\mathrm{Al}(\mathrm{OH})_{3}\right)$ and 26.6 moles of quartz $\left(\mathrm{SiO}_{2}\right)$. The elemental composition of the mineral assemblage can be expressed as $\left(\mathrm{Al}_{7} \mathrm{Si}_{35} \mathrm{Mg}_{2.9} \mathrm{~K}_{1.8} \mathrm{Na}(\mathrm{OH})_{13.7} \mathrm{O}_{78}\right)$ (MW: 2822). Since particulate $\mathrm{Al}$ and Fe contents correlate very well (Table 4), one may further include iron (oxy)hydroxides according to the stoichiometric proportion found in the trap material ( $\mathrm{Al}: \mathrm{Fe}$ $=2: 1$ ) resulting in $\mathrm{Al}_{7} \mathrm{Si}_{35} \mathrm{Fe}_{3.5} \mathrm{Mg}_{2.9} \mathrm{~K}_{1.8} \mathrm{Na}(\mathrm{OH})_{17.2} \mathrm{O}_{81.5}$. 
Vertical and horizontal contributions to the fluxes of particles, organic matter, calcium carbonate and silicate minerals

Time-weighted mean fluxes $\overline{\mathrm{F}}_{\mathrm{j}, \mathrm{i}}$, of particles, calcium carbonate, organic matter or silicate minerals were estimated from the fluxes, $\overline{\mathrm{F}}_{\mathrm{j}, \mathrm{i}}$, measured during the triweekly periods of deployment, $\Delta \mathrm{t}$, of the sediment traps, $\mathrm{i}$, according to:

$$
\overline{\mathrm{F}}_{\mathrm{j}, \mathrm{i}}=\frac{\sum \overrightarrow{\mathrm{F}}_{\mathrm{j}, \mathrm{i}}(\Delta \mathrm{t}) \Delta \mathrm{t}}{\sum \Delta \mathrm{t}} \quad\left[\mathrm{g} \mathrm{m}^{-2} \mathrm{~d}^{-1} \text { or } \mathrm{mol} \mathrm{m}^{-2} \mathrm{~d}^{-1}\right]
$$

where $\mathrm{j}$ denote either particle mass, $\mathrm{Ca}$ (representing calcium carbonate), organic $\mathrm{C}$ (representing organic matter) or $\mathrm{Al}$ (representing silicate minerals) fluxes, respectively (Table 3). The relative flux ratio, $\mathrm{R}_{\mathrm{j}, \mathrm{i}}$, of a sediment trap can be given as the fluxes of particles or the main constituents, respectively, normalised to the flux recorded by the $40 \mathrm{~m}$ trap at station A according to:

$$
R_{j, i}=\frac{\bar{F}_{j, i}}{\bar{F}_{j, A 40 m}}
$$

Hence, any increase or decrease in flux is related to the flux measured by the sediment trap with maximum distance to the margin of the lake. Vertical profiles of the relative flux ratios are displayed in Figures $7 \mathrm{a}-\mathrm{d}$. Vertical $\left(\mathrm{F}_{\mathrm{v}}\right)$ and horizontal (or lateral) $\left(\mathrm{F}_{\mathrm{L}}\right)$ flux components of total fluxes are separated which allows us to interpret an increase in the relative flux with depth in terms of higher lateral flux contributions.

Figure 7a shows that particle fluxes in the near-surface traps increased in the shoreward direction. At station B, the vertical flux recorded by the $40 \mathrm{~m}$ trap was about $15 \%$ higher than the flux measured at the same water depth in the centre of the lake. Note that enhanced fluxes of organic matter and silicate minerals account for this increase (Figs. 7c and d) rather than an increase in $\mathrm{CaCO}_{3}$ flux (Fig. 7b). The average particle flux at station $\mathrm{C}$, the station located in the littoral zone close to the edge of the shallow, southern basin of Lake Zurich, was almost double the average particle flux recorded by the $40 \mathrm{~m}$ trap at station $\mathrm{A}$. The flux increase at station $\mathrm{C}$ is due to higher inputs of all constituents, i.e., $\mathrm{CaCO}_{3}$, organic matter and silicate minerals (Figs. $7 \mathrm{~b}, \mathrm{c}$ and d). Note that both primary production and horizontal sediment transport may affect the fluxes of organic matter and $\mathrm{CaCO}_{3}$ in the littoral zones of the lake. Increasing fluxes of silicate minerals in the shoreward direction, however, indicate significant horizontal contributions to sediment transport. Lateral sediment transport is further indicated by the vertical profiles. Figure 7a shows that particle fluxes at stations $\mathrm{A}$ and $\mathrm{B}$ depended on the vertical position of the sediment traps. Lateral contributions to the particle flux at station B were estimated to be $5 \%$ for the $70 \mathrm{~m}$ trap and to be $15 \%$ for the $100 \mathrm{~m}$ trap. Note the higher fluxes of silicate minerals and organic matter in the near-bottom trap at station B indicating lateral particle inputs (Figs. $7 \mathrm{c}$ and d). Lateral contributions of organic matter and silicate minerals were estimated to be $17 \%$ and $30 \%$ of the total fluxes. Thus, the lateral flux contributions of organic matter and silicate minerals were significantly higher than the lateral $\mathrm{CaCO}_{3}$ inputs (8\%) (Fig. 7b). However, 
Relative mass flux

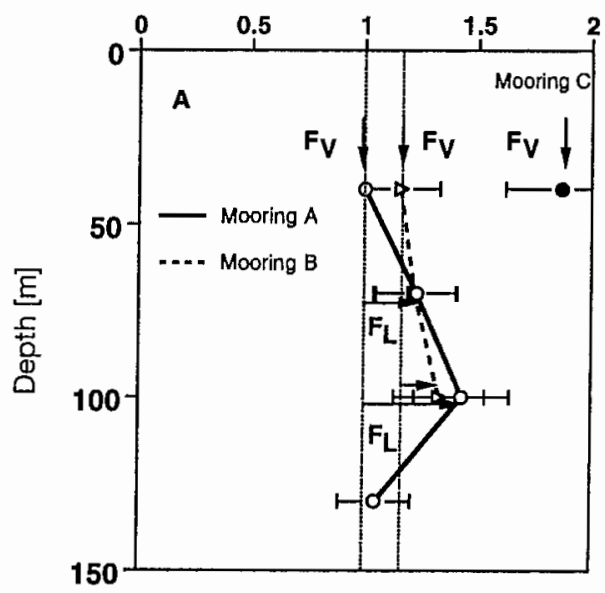

Relative organic $\mathrm{C}$ flux

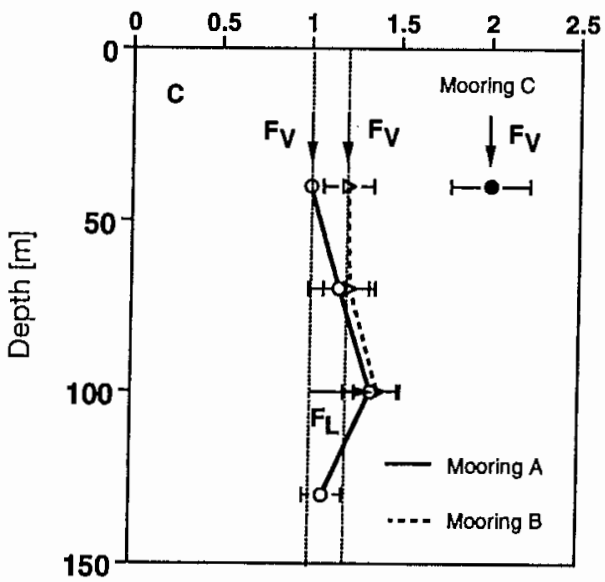

Relative Ca flux

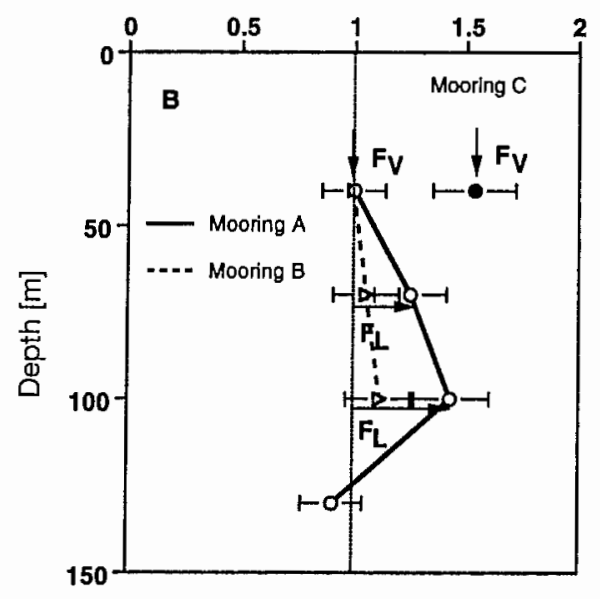

Relative Al flux

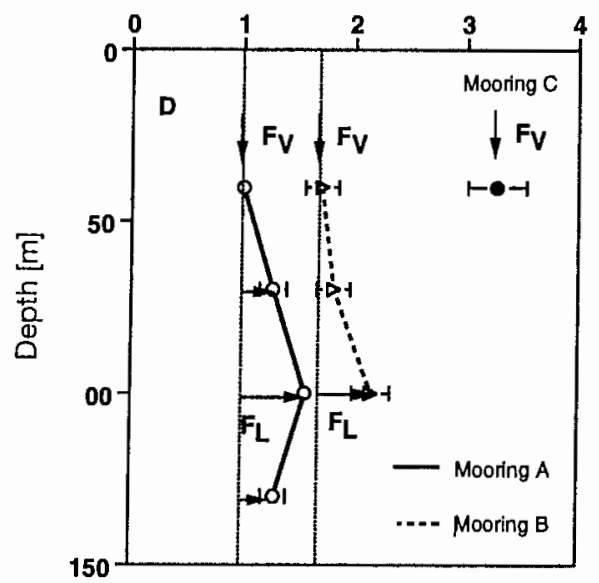

Figure 7a-d. Relative flux ratios of A) particle mass, B) calcium, C) organic carbon and D) aluminium. Flux ratios are separated into vertical $\left(F_{V}\right)$ and horizontal (i.e., lateral) $\left(F_{\mathrm{L}}\right)$ flux contributions

since the organic matter and silicate mineral fractions in sedimentary material were small, the resulting increase in mass flux falls within the estimated uncertainty of the sampling technique. Figures $7 \mathrm{c}$ and $\mathrm{d}$ further illustrate that the fluxes of organic matter and silicate minerals were also dependent on the water depth at station $A$. Lateral contributions of organic matter and silicate minerals were estimated to be $16 \%$ and $20 \%$ of the total flux in the $70 \mathrm{~m}$ trap, $34 \%$ and $39 \%$ in the $100 \mathrm{~m}$ trap as well as $8 \%$ and $30 \%$ in the near-bottom trap, respectively. The flux pattern observed along the transect reveals that organic matter and silicate minerals were swept downslope from the shallow to the central basin of Lower Lake Zurich. 

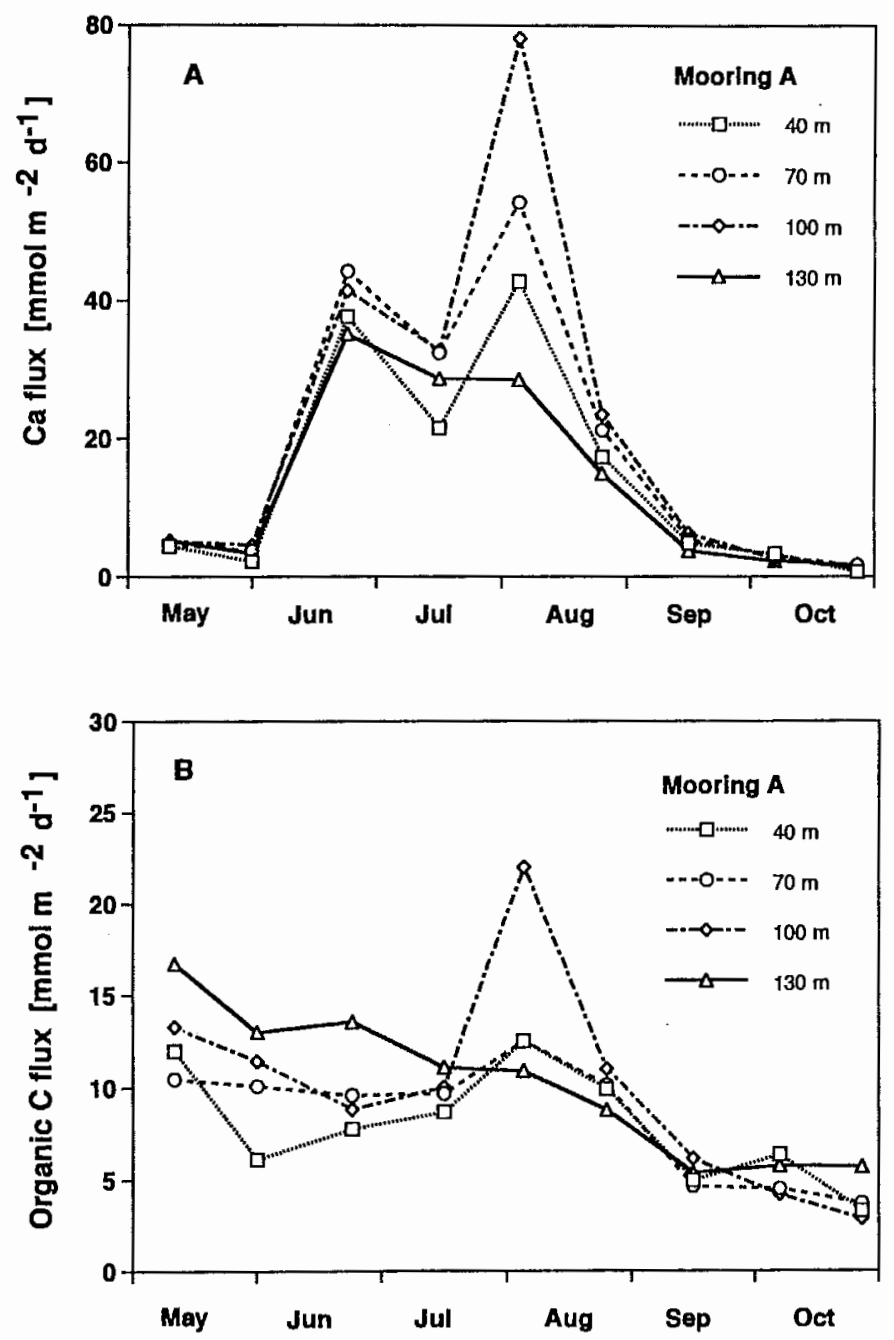

Figure 8 a, b. Seasonal variations in the calcite and organic carbon fluxes measured at sampling site A: A) calcite and B) organic carbon

At station A, the vertical profile of the total mass flux is governed by the flux of $\mathrm{CaCO}_{3}$ (Figs. $7 \mathrm{a}$ and b), mainly by an episodic event of $\mathrm{CaCO}_{3}$ precipitation observed between 13 July and 3 August. Figure 8 a shows that the flux of $\mathrm{CaCO}_{3}$ increased at this station between June and August up to a maximum input between 13 July and 3 August. This event was recorded simultaneously in the $40 \mathrm{~m}, 70 \mathrm{~m}$ and the $100 \mathrm{~m}$ traps at station $\mathrm{A}$, but was not detected in the traps deployed at stations B and $\mathrm{C}$ (Fig. $8 \mathrm{c}$ ). Hence, $\mathrm{CaCO}_{3}$ precipitation occurred locally in the epilimnion, i.e., in the zone between mooring $\mathrm{A}$ and $\mathrm{B}$, during a summer maximum in primary production $\left(12 \mu \mathrm{g} \mathrm{L}^{-1} \mathrm{C}\right.$ production, $\mathrm{T} \sim 21^{\circ}, \mathrm{pH} \sim 8.5$; Zimmermann et al., 1993) causing a patchy input of $\mathrm{CaCO}_{3}$ and organic material to the hypolimnetic traps at 

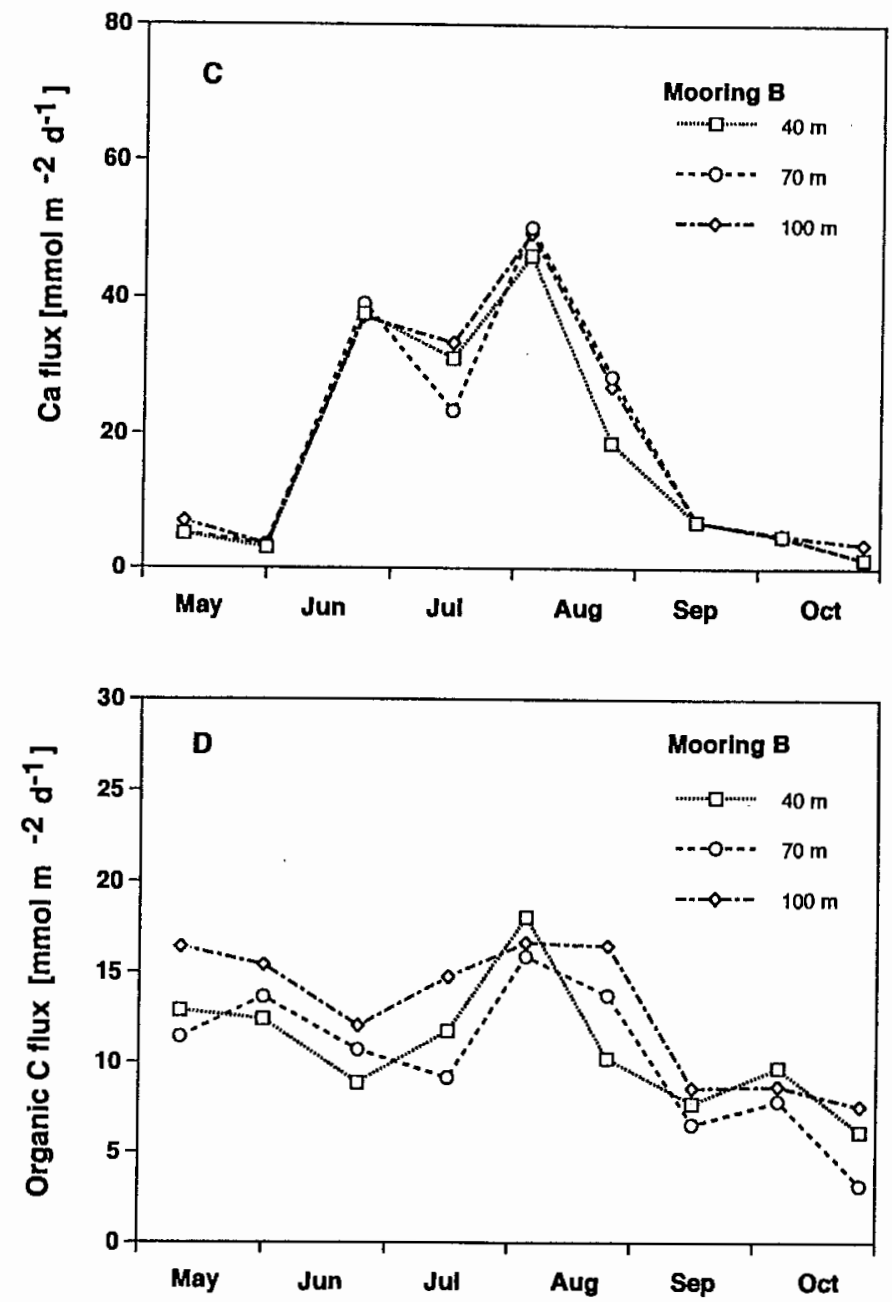

Figure $8 \mathrm{c}$, d. Seasonal variations in the calcite and organic carbon fluxes measured at sampling site B: C) calcite and D) organic carbon

station A. Coinciding with this episodic event of $\mathrm{CaCO}_{3}$ precipitation, a substantial decrease in the average concentration of dissolved $\mathrm{Ca}$ from $1.16 \mathrm{mmol} \mathrm{L}^{-1}$ to 0.98 mmol L ${ }^{-1}$ was recorded in the epilimnion (0-15 m) (Zimmermann, 1993). Note that the patchiness of $\mathrm{CaCO}_{3}$ precipitation is a phenomenon well-documented for hardwater lakes (e.g., Pulvermüller et al., 1995). This episodic event of $\mathrm{CaCO}_{3}$ precipitation was not recorded in the $130 \mathrm{~m}$ trap at station A. Figure 7 a shows that the average mass flux increased from $40 \mathrm{~m}$ to $100 \mathrm{~m}$ water depth, but was significantly diminished in the near-bottom trap. Note that, simultaneously, the fluxes of organic matter and silicates were reduced in the $130 \mathrm{~m}$ trap compared to the overlying $100 \mathrm{~m}$ trap (Figs. $7 \mathrm{c}$ and d). Assuming that no experimental artefacts were involved, two explanations are possible: $\mathrm{CaCO}_{3}$ and particulate organic matter, while sedi- 
menting through the near-bottom layers at station A, dissolved or degraded, respectively, during transit, or all components were prevented from being entrapped in the near-bottom trap. First, we explore the possibility of complete $\mathrm{CaCO}_{3}$ dissolution in the near-bottom water layers by mass balance calculations. The saturation index, (IAP/K), indicates whether the lake water was undersaturated, saturated, or supersaturated with respect to $\mathrm{CaCO}_{3}$ (Stumm and Morgan, 1996). The ion activity product $\left[\mathrm{IAP}=\left(\mathrm{Ca}^{2+}\right)\left(\mathrm{CO}_{3}^{2-}\right)\right]$ was estimated using measurements of the relevant geochemical parameters ( $\mathrm{pH}$, calcium hardness, carbonate hardness) in the water column measured on 5 July, 1989, by the Zurich Water Supply Authority (Zimmermann, 1993). The calculations show that the bottom water below $100 \mathrm{~m}$ water depth was undersaturated with respect to calcite (IAP $=0.45)$ which corresponds to previous computations of the saturation index for Lake Zurich water (Stumm and Stumm-Zollinger, 1968; Kelts and Hsü, 1978). Between 13 July and 3 August the concentration of $\mathrm{Ca}^{2+}$ determined as calcium hardness increased in the near-bottom water below $110 \mathrm{~m}$ water depth from $1.28 \mathrm{mmol} \mathrm{L}^{-1}$ to $1.31 \mathrm{mmol} \mathrm{L}^{-1}$. The flux of $\mathrm{CaCO}_{3}$ into the near-bottom waters below $100 \mathrm{~m}$ water depth was calculated from the difference in the average Ca flux to the $100 \mathrm{~m}$ and $130 \mathrm{~m}$ traps at station $\mathrm{A}$. The flux of $\mathrm{CaCO}_{3}$ into the bottom water was estimated to be $50 \mathrm{mmol}$ $\mathrm{m}^{-2} \mathrm{~d}^{-1}$ or $1.05 \mathrm{~mol} \mathrm{~m}^{-2}$, respectively, for a deployment period of 21 days. Thus, complete dissolution of the $\mathrm{CaCO}_{3}$ contribution would have caused an increase in the average Ca concentration in the near-bottom water below $110 \mathrm{~m}$ water depth from $1.28 \mathrm{mmol} \mathrm{L}^{-1}$ to $1.36 \mathrm{mmol} \mathrm{L}^{-1}$. Expected $\left(1.36 \mathrm{mmol} \mathrm{L}^{-1}\right)$ and observed $\left(1.31 \mathrm{mmol} \mathrm{L}^{-1}\right) \mathrm{Ca}$ concentrations differ slightly, indicating that both processes, i.e., the dissolution of $\mathrm{CaCO}_{3}$ in the bottom water and incomplete flux measurements, may have caused such a pronounced decrease in the flux of $\mathrm{CaCO}_{3}$ at $130 \mathrm{~m}$ water depth. We believe that dissolution of $\mathrm{CaCO}_{3}$ in the water and possibly, artifactually in the bottom traps, may have accounted for at least some reduction in $\mathrm{CaCO}_{3}$ fluxes below $100 \mathrm{~m}$ water depth. By contrast, incomplete flux measurements could be due to the presence of a benthic nepheloid layer of suspended matter caused by a density gradient across the oxic-anoxic boundary in the water. Such a nepheloid layer, which was observed by one of us (PHS) during a dive to the anoxic lake bottom, could have caused the reduction of the fluxes not only of $\mathrm{CaCO}_{3}$, but also of organic matter and silicate minerals (Figs. $7 \mathrm{c}$ and d). The reduction of all components of the settling material corresponds to an increase in suspended matter concentration of about $0.5 \mathrm{mg} \mathrm{L}^{-1}$, thus actually producing a nepheloid layer at the lake bottom.

In previous studies reported by Schuler et al. (1991) and Wieland et al. (1991), sediment focusing by lateral transport was suggested to be an effective mechanism for in-lake movement of radionuclides and trace elements associated with finegrained particles in Lake Zurich. Here, we have demonstrated that silicate minerals, organic material and, less effectively, calcium carbonate can be swept along the sediments in the transitional area between the two basins to deeper-lying sediments in the centre of the lake. Therefore, organic material and silicate minerals entrapped in the central part of Lake Zurich may also have originated from the plume of particles recorded in the sediment trap at station $\mathrm{C}$. As indicated by differences in lateral flux contributions of the constituents, lateral transport of $\mathrm{CaCO}_{3}$ was decoupled from that of organic material and silicate minerals in the transitional area 
most likely due to differences in dispersion (particle size distribution) and patchiness of the particles. On the other hand, similar patterns in the in-lake distribution of organic matter and silicate minerals presumably indicate close association of these constituents due to aggregation processes. A significant reduction in the sedimentation rate at $130 \mathrm{~m}$ water depth indicates that in-lake processes may affect particle sedimentation in the slightly denser anoxic bottom waters. The sedimentation rate of $\mathrm{CaCO}_{3}$ determined from mid-depth traps could thus overestimate the net flux to the sediments.

\section{Concentrations of major and minor elements in settling material}

To assess the impact of in-lake processes on the element distribution in Lake Zurich, the concentrations of major and minor elements were compared for the settling material collected in the near-surface and near-bottom traps at stations $\mathrm{A}$ and $B$. Average particulate concentrations of each element in the samples were calculated and normalised to the particulate Ca concentration. The Ca normalised elemental ratios are given by:

$$
\text { Ratio }=\left([\mathrm{E}]_{\mathrm{s}} /[\mathrm{Ca}]_{\mathrm{s}}\right) \times\left([\mathrm{Ca}]_{\mathrm{b}} /[\mathrm{E}]_{\mathrm{b}}\right)
$$

where $[\mathrm{E}]_{\mathrm{s}}$ and $[\mathrm{E}]_{\mathrm{b}}$ denote the particulate concentrations of an element in the $40 \mathrm{~m}$ $(\mathrm{s}=$ surface $)$ and $130 \mathrm{~m}$ traps $(\mathrm{b}=$ bottom $)$ at stations $\mathrm{A}$ or $\mathrm{B}$, respectively, and $[\mathrm{Ca}]_{\mathrm{s}}$ and $[\mathrm{Ca}]_{b}$ are the $\mathrm{Ca}$ concentrations of these samples. The ratios are displayed in Figure 9. Ratios lower than one indicate accumulation of an element in the nearbottom sediment trap.

Strontium is the only element, which was not significantly accumulated with respect to $\mathrm{Ca}$ in near-bottom samples. Sr removal from the water column appears to be strongly linked to $\mathrm{CaCO}_{3}$ as indicated by the significant correlation of particulate $\mathrm{Sr}$ and $\mathrm{Ca}$ concentrations $(\mathrm{r}=0.87$ in Table 4$)$. The $\mathrm{Ca} / \mathrm{Sr}$ stoichiometry was determined to be about $1000: 1$ for samples with particulate $\mathrm{Ca}$ concentrations $\leq 4 \mathrm{mmol} \mathrm{g}^{-1}$, i.e., samples collected in spring and late summer, and about 2550:1 in settling particles sampled during the summer maximum. The corresponding $\mathrm{Sr} / \mathrm{Ca}$ ratios defined as atoms Sr/atoms $\mathrm{Ca}$ amount to $(1 \pm 0.2) \times 10^{-3}$ during spring and late summer when the content of $\mathrm{CaCO}_{3}$ in the settling material was low, and $(0.39 \pm 0.08) \times 10^{-3}$ during the summer maximum when precipitation of $\mathrm{CaCO}_{3}$ occurred. Note that Sigg et al. (1987) reported a Sr/Ca atom ratio of in the range $2.5 \times 10^{-3}$ to $3.5 \times 10^{-3}$ for Lake Zurich. For Lake Constance, the $\mathrm{Sr} / \mathrm{Ca}$ ratio was determined to be $0.84 \times 10^{-3}$ (Stabel, 1989). Since the concentrations of dissolved $\mathrm{Sr}$ in lake water never reach saturation with respect to $\mathrm{SrCO}_{3}$, Sr elimination occurs via coprecipitation with $\mathrm{CaCO}_{3}$ (Sigg et al., 1987; Stabel, 1989). It was reported that $\mathrm{Sr}$ can be taken up to minor extent by $\mathrm{CaCO}_{3}$ in its rhombohedral form (calcite), but in larger quantities by the orthorhombic form (aragonite) (Speer, 1983). Note that the particulate $\mathrm{Sr} / \mathrm{Ca}$ ratio was found to vary seasonally in Lake Zurich. Scavenging efficiency is lower during periods of $\mathrm{CaCO}_{3}$ precipitation, that is during the summer maximum in mass flux. Thus, the seasonal variation in the $\mathrm{Sr} / \mathrm{Ca}$ ratio may indicate either association of $\mathrm{Sr}$ with $\mathrm{CaCO}_{3}$ of different origins (allochthonous 


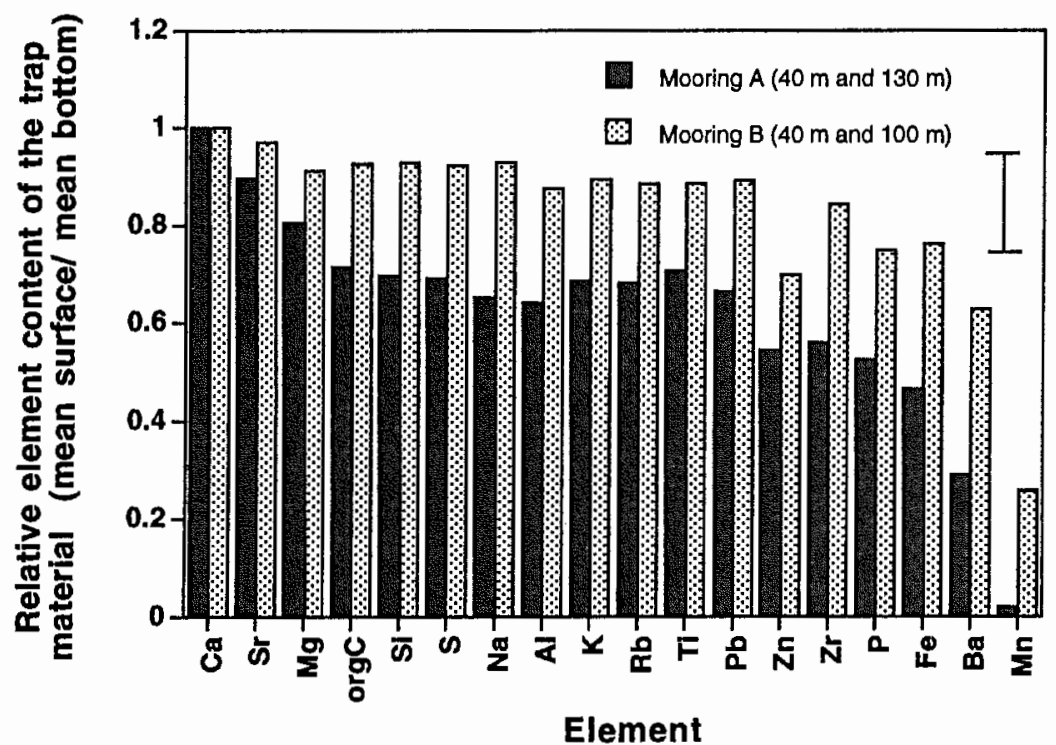

Figure 9. Comparison of the element concentrations on sedimentary material collected in the near-surface and near-bottom sediment traps at sites $\mathrm{A}$ and $\mathrm{B}$. The relative element content is given as $\mathrm{Ca}$ normalised ratios of the particulate concentrations of an element. Values below the reference line (relative element content $=1$ ) indicate accumulation of the element in the nearbottom sediment trap

versus autochthonous) or of different forms and degrees of crystallization (aragonite versus calcite, slow versus fast $\mathrm{CaCO}_{3}$ precipitation).

Sedimentary sulfur in Lake Zurich is mainly held in the organic form, as indicated by the strong correlation of organic $\mathrm{C}$ and $\mathrm{S}$ (Table 4). The ratio $\mathrm{C}_{\mathrm{org}} / \mathrm{S}$ is estimated to 74 . This value is within the range reported for sulfur contents in algae and mixed plankton $\left(\mathrm{C}_{\mathrm{org}} / \mathrm{S}=43-100\right.$; Losher and Kelts, 1989). Note that XRF measurements account for the total sulfur content of settling particles rather than the organic fraction. However, inorganic $S$ is expected to be low due to strong undersaturation of the lake water with respect to all metal sulfates, and the likely oxidation of metal sulfides, should they have occurred, by oxygen. Therefore, organic sulfate esters and thiols might predominate.

Magnesium and sodium are assumed to be predominantly associated with silicate minerals. However, vertical profiles of the particulate concentrations and the flux ratios of $\mathrm{Mg}$ and $\mathrm{Na}$ (not shown) were similar to those of $\mathrm{Ca}$ (Figs. 5a and 7b). For example, the peak in Ca input recorded in the $70 \mathrm{~m}$ and $100 \mathrm{~m}$ traps at mooring A (Fig. 8 a) also appears in the flux profiles of $\mathrm{Mg}$ and $\mathrm{Na}$. Thus, $\mathrm{Mg}$ and $\mathrm{Na}$ distributions seem to be partially affected by $\mathrm{CaCO}_{3}$ precipitation and partially by the transport of silicate minerals. Based on a stoichiometric ratio of $\mathrm{Al}: \mathrm{Mg}: \mathrm{Na}=7: 3: 1$ for the silicate fraction (see previous section), we estimate that silicate minerals accounted for at a maximum of $60 \%$ or $74 \%$, respectively, of the total $\mathrm{Mg}$ and $\mathrm{Na}$ fluxes to the sediments during stratification of the lake. Thus, $\mathrm{Mg}$ and $\mathrm{Na}$ fluxes 
were significantly enhanced during the summer maximum due to coprecipitation with $\mathrm{CaCO}_{3}$.

Some elements which act as tracers of main constituents in the settling material, that is organic $\mathrm{C}$ for organic matter and $\mathrm{Al}, \mathrm{Si}$ (except during spring and early summer), $\mathrm{K}, \mathrm{Rb}, \mathrm{Ti}, \mathrm{Zr}$ for silicate minerals were enriched with respect to $\mathrm{Ca}$ in the near-bottom samples. As previously discussed, this enrichment can be ascribed to sediment focusing. Note that, in the case of $\mathrm{Zr}$, an additional removal mechanism may be operative at $130 \mathrm{~m}$ water depth, e.g., scavenging by iron or manganese (oxy)hydroxides.

The concentrations of iron and phosphate were higher on the near-bottom materials (Fig. 9). Moreover, both elements were slightly enriched with regard to their main carrying phases, that is, $\mathrm{P}$ with regard to organic matter (represented by org $\mathrm{C}$ ) and $\mathrm{Fe}$ with regard to silicate minerals (represented by $\mathrm{Al}$ ). Redoxprocesses occurring at the sediment-water interface were found to cause accumulation of particulate $\mathrm{Fe}$ in the near-bottom water layers (Davison, 1985; Sigg et al., 1991). Accumulation of $\mathbf{P}$ in the near-bottom sediment traps may be explained by an increase in the bacterial P content with depth (Gächter and Bloesch, 1985).

Figure 9 further shows that $\mathrm{Pb}$ and $\mathrm{Zn}$ are accumulated in the near-bottom traps at stations $\mathrm{A}$ and $\mathrm{B}$ indicating scavenging by organic matter and/or the mineralic particle fraction. In the case of $\mathrm{Zn}$, an additional removal mechanism such as scavenging by iron (oxy)hydroxides may be operative accounting for the significant enrichment in the near-bottom traps at both stations.

In this study, barium is the only element which appears to be strongly linked to the redox cycle of $\mathrm{Mn}$ in the anoxic bottom water of Lake Zurich (Fig. 9). Ba and $\mathrm{Mn}$ show maximum accumulation in the $130 \mathrm{~m}$ trap at station $\mathrm{A}$, and significantly increased concentrations on the settling material collected by the near-bottom trap at station B. Manganese oxides may be formed in a tunnel managanate-type structure at the redox boundary of the water column caused by the oxidation of $\mathrm{Mn}$ (II) to $\mathrm{Mn}$ (IV). (Friedl et al., 1997). The tunnel structure is stabilised by large cations such as $\mathrm{Ba}^{2+}, \mathrm{K}^{+}$etc. (Giovanoli, 1986) accounting for the significant enhancement of $\mathrm{Ba}$ scavenging by manganese oxides in the anoxic bottom waters.

The results presented above demonstrate that in-lake particle dynamics such as episodic events of $\mathrm{CaCO}_{3}$ precipitation, manganese cycling in the anoxic bottom waters, and sediment focusing affect the distribution of elements in the lake. Sediment focusing plays a prominent role for the in-lake distribution of contaminants, which are associated with organic matter and the silicate fraction.

\section{Summary and Conclusions}

1) The temporal and spatial variations in particle fluxes were investigated during stratification of Lower Lake Zurich using a two-dimensional array of sediment traps deployed along the longitudinal section. This setting allowed a distinctive separation of vertical and horizontal (i.e., lateral) flux contributions along the transition between the shallow, southern basin and the main, northern basin of Lower Lake Zurich. 
2) The main constituents of settling particles, as inferred from this study, were $\mathrm{CaCO}_{3}$, organic material $\left(\left(\mathrm{CH}_{2} \mathrm{O}\right)_{95}\left(\mathrm{NH}_{3}\right)_{18} \mathrm{HPO}_{4}\right)$, biogenic silica, an aggregate of silicate and iron minerals, consisting of alkali feldspars, micas, quartz and aluminium and iron (oxy)hydroxides and represented by the stoichiometric formula $\mathrm{Al}_{7} \mathrm{Si}_{35} \mathrm{Fe}_{3.5} \mathrm{Mg}_{2.9} \mathrm{~K}_{1.8} \mathrm{Na}(\mathrm{OH})_{17.2} \mathrm{O}_{81.5}$ ), and manganese oxides. Seasonal inputs of biogenic silica in spring and early summer and calcium carbonate in mid-summer were observed. Seasonal fluctuations in $\mathrm{MnO}_{2}$ production caused by managanese cycling were recorded in deep sediment traps below $100 \mathrm{~m}$ water depth.

3) Differences in particle composition and the fluxes of the individual constituents (calcium carbonate, organic matter and silicate minerals) were controlled by the following processes: 1) Increase in particle sedimentation in the shoreward direction indicated by an increase in measured sedimentation rates and caused by bottom sediment resuspension in shallow waters and an increased primary productivity in the littoral zone, 2) lateral transport of mainly organic matter and silicate minerals from the shallow, southern basin into the main, northern basin of Lake Zurich, causing sediment focusing, 3) episodic and patchy events of $\mathrm{CaCO}_{3}$ precipitation in the epilimnion followed by sedimentation, and 4) lateral particle transport of fine-grained particles in the near-bottom anoxic waters causing the formation of a patchy benthic nepheloid layer.

4) During stratification of the lake, sediment focusing by lateral pathways gave rise to particle transport between the two basins of Lake Zurich which led to increased fluxes of organic matter and silicate minerals to deeper-lying sediments in the centre of the lake. Therefore, sediment focusing can greatly affect the post-depositional redistribution of contaminants between the two basins of Lake Zurich.

5) The anoxic water layers at the bottom of the main basin of Lower Lake Zurich may influence particle fluxes below $100 \mathrm{~m}$ water depth as indicated by reduced fluxes of $\mathrm{CaCO}_{3}$, organic matter and silicate minerals between the $100 \mathrm{~m}$ and $130 \mathrm{~m}$ sediment traps at station A.

6) Sedimentation of predominantly silicate-controlled elements ( $\mathrm{Al}, \mathrm{K}, \mathrm{Fe}, \mathrm{Ti}$, $\mathrm{Zr}, \mathrm{Rb}$ ), largely biological-controlled elements (org C, N, P, S, Si) and redoxcontrolled elements ( $\mathrm{Mn}$ and $\mathrm{Ba}$ ) in the near-bottom traps at mooring $\mathrm{A}$ and $B$ suggest that organic matter, silicate minerals, manganese and iron (oxy)hydroxides, which pass through the lake water, end up accumulating at the bottom sediments, unlike $\mathrm{CaCO}_{3}$, whose flux below $100 \mathrm{~m}$ was greatly attenuated.

7) Our results demonstrate that information concerning seasonal fluctuations and spatial variations in particle fluxes is required for a detailed understanding of particle dynamics in Lake Zurich. We also conclude that in-lake mixing processes are ineffective in levelling out spatial variations in the concentration of suspended particles. Thus, sediment trap fluxes may vary considerably with distance from the shore and with depth. 


\section{ACKNOWLEDGEMENTS}

This research was carried out at the Swiss Institute for Water Resources and Water Pollution Control (EAWAG), CH-8600 Dübendorf. We would like to acknowledge the help provided by Dr. M. Sturm on planning the sedimentological part of this study. The help of A. Zwyssig with the deployment and retrieval of the sediment traps is kindly acknowledged. We thank the Zurich Water Supply Authority for permission to use the limnological data on Lake Zurich, and Drs. J. Beer (EAWAG/ETH Zurich) and D. Imboden (ETH Zurich) for the effort they took in considering an earlier version of the manuscript. The thoughtful comments by Drs. J. Bloesch and H.R. von Gunten as well as an anonymous reviewer are gratefully acknowledged. The work was in part funded by EAWAG, the Texas Institute of Oceanography (TAMUG) to P.S., and the Swiss NSF with a grant to E.W.

\section{REFERENCES}

Biscaye, P.E., R.F. Anderson and B.L. Deck, 1988. Fluxes of particles and constituents to the eastern United States continental slope and rise: SEEP-I. Continental Shelf Research 8: 855-904.

Bloesch, J. and N.M. Burns, 1980. A critical review of sedimentation trap teclnique. Schweiz. Z. Hydrol. 42: 15-55.

Bloesch, J. and U. Uehlinger, 1986. Horizontal sedimentation differences in a eutrophic Swiss lake. Limnol. Oceanogr. 31: 1094-1109.

Bloesch, J., 1995. Mechanisms, measurements and importance of sediment resuspension in lakes. Mar. Fresliwater Res. 46: 295-304.

Chambers, R.L. and B.J. Eadie, 1981. Nepheloid and suspended particle matter in southeastern Lake Michigan. Sedimentology 28: 438-447.

Davison, W., 1985. Conceptual models for transport at redox boundary. In: W. Stumm (ed.), Chemical Processes in Lakes, Wiley Interscience, New York, pp. 31-53.

Downing, J.A. and E. McCauley, 1992. The nitrogen: phosplorous relationship in lakes. Limnol. Oceanogr. 37: 936-945.

Eadie, B.J. and J. A. Robbins, 1987. The role of particulate matter in the movement of contaminants in the Great Lakes. In: R.A. Hites and S.J. Eisenreich (eds.), Sources and Fates of Aquatic Pollutants, ACS Advances in Chemistry Series, Washington, pp. 319-364.

Friedl, G., B. Welirli and A. Manceau, 1997. Solid phase in the cycling of manganese in eutrophic lakes: New insights from EXAFS spectroscopy. Geochim. Cosmochim. Acta 61, 275-290.

Gächter, R. and J. Bloesch, 1985. Seasonal and vertical variation in the C:P ratio of suspended and settling seston of lakes. Hydrobiologia 128: 193-200.

Garett, C., 1990. The role of secondary circulation in boundary mixing. J. Geophys. Res. 95: 3181-3188.

Giovanoli, R., R. Brütsch, D. Diem, G. Osman-Sigg and L. Sigg, 1980. The composition of settling particles in Lake Zurich. Schweiz. Z. Hydrol. 42: 89-100.

Giovanoli, R., 1986. Manganese oxide minerals. Transactions of the XIIIth Congress of the International Society of Soil Science, pp. 335-345.

Grütter, A., H.R. von Gunten, M. Kohler and E. Rössler, 1990. Sorption, desorption and exchange of cesium on glaciofluvial deposits. Radiochim. Acta 50: 177-184.

Hakanson, L. and M. Jansson, 1983. Principles of Lake Sedimentology. Springer, New York, 316 pp.

Hilton, J., 1985. A conceptual framework for predicting the occurrence of sediment focusing and sediment redistribution in small lakes. Limnol. Oceanogr. 30: 1131-1143.

Hilton, J., J.P. Lishman and P.V. Allen, 1986. The dominant processes of sediment distribution and focusing in a small, eutrophic, monomictic lake. Limnol. Oceanogr. 31: 125-133.

Höhener P. and R. Gächter, 1993. Prediction of dissolved inorganic nitrogen (DIN) concentrations in deep, seasonally stratified lakes based on rates of DIN input and $\mathrm{N}$ removal processes. Aquatic Sciences 55: 112--131.

Hsü, K.J. and K.R. Kelts, 1970. Seisnic investigations of Lake Zurich: Part II Geology. Eclogae Geol. Helv. 63: 525-38. 
Kelts, K. and K.J. Hsü, 1978. Freshwater carbonate sedimentation. In: A. Lerman (ed.). Lakes: Chemistry - Geology - Physics, Springer Verlag, New York, pp. 295-323.

Losher, A.J. and K.R. Kelts, 1989. Organic sulphur fixation in freshwater lake sediments and the implication for C/S ratios. Terra Nova 1: 253-261.

Murray, J.W., 1987. Mechanisms controlling the distribution of trace elements in oceans and lakes. In: R.A. Hites and S.J. Eisenreich (eds.). Sources and Fates of Aquatic Pollutants. ACS Advances in Chemistry Series, Washington, pp. 153-184.

Pulvermüller, A.G., J. Kleiner and W. Mauser, 1995. Calcite patchiness in Lake Constance as viewed by LANDSAT-TM. Aquatic Sciences 57: 338-349.

Santschi, P.H., 1984. Particle flux and trace metal residence times in natural waters. Limnol. Oceanogr. 29: 1100-1108.

Schuler, C., E. Wieland, P.H. Santschi, M. Sturm, A. Lueck, S. Bollhalder, J. Beer, G. Bonani, H.J. Hofmann, M. Suter and W. Woelfli, 1991. A multitracer study of radionuclides in Lake Zurich, Switzerland. I. Comparison of atmospheric and sedimentary fluxes of ${ }^{7} \mathrm{Be},{ }^{10} \mathrm{Be},{ }^{210} \mathrm{~Pb}$, ${ }^{210} \mathrm{Po}$, and ${ }^{137} \mathrm{Cs}$. J. Geophys. Res. 96: 17051-17065.

Sigg, L., 1985. Metal transfer mechanisms in lakes; the role of settling particles. In: W. Stumm (ed.), Chemical Processes in Lakes, Wiley Interscience, New York, pp. $284-310$.

Sigg, L., M. Sturm and D. Kistler, 1987. Vertical transport of heavy metals by settling particles in Lake Zurich. Limnol. Oceanogr. 32: 112-130.

Sigg, L., C.A. Johnson and A. Kuhn, 1991. Redox conditions and alkalinity generation in a seasonally anoxic lake (Lake Greifen). Mar. Chem. 36: 9-26.

Speer, J.A., 1983. Crystal chemistry and phase relations of orthorhombic carbonates. In: R.J. Reeder (ed.). Carbonates: Mineralogy and Chemistry, Reviews in Mineralogy 11: 145-225.

Stabel, H.H., 1989. Coupling of strontium and calcium cycles in Lake Constance. Hydrobiologia 176/177: 323-329.

Stumm, W. and E. Stumm-Zollinger, 1968. Chemische Prozesse in natürlichen Gewässern. Chimia 22: 325-337.

Stumm, W. and J.J. Morgan, 1996. Aquatic Chemistry 3 rd ed., Wiley Interscience, New York, $796 \mathrm{pp}$.

Sturm, M., U. Zeh, J. Müller, L. Sigg and H.H. Stabel, 1982. Schwebstoffuntersuchungen im Bodensee mit Intervall-Sedimentationsfallen. Eclogae Geol. Helv. 75: 579-588.

Wieland, E., P.H. Santschi and J. Beer, 1991. A multitracer study of radionuclides in Lake Zurich, Switzerland. 2. Residence times, removal processes, and sediment focusing. J. Geophys. Res. 96: $17067-17080$.

Zimmermann, U., Forster, R. and H. Sontheimer, 1992. Long-term changes of water quality in three Swiss lakes (Lake Zurich, Zurichobersee and Lake Walenstadt). Zurich Water Supply Authority, Zurich.

Zimmermann, U., 1993. Personal communication.

Received 17 November 1999;

revised manuscript accepted 24 November 2000. 